\title{
Synthesis, Properties, and Enzymatic Hydrolysis of Poly(lactic acid)-co-Poly(propylene adipate) Block Copolymers Prepared by Reactive Extrusion
}

\author{
Zoi Terzopoulou ${ }^{1, *(\mathbb{C})}$, Alexandra Zamboulis ${ }^{1}{ }^{(D}$, Dimitrios N. Bikiaris ${ }^{1}\left(\mathbb{D}\right.$, Miguel Angel Valera $^{2}$ \\ and Ana Mangas 2 (D) \\ 1 Laboratory of Chemistry and Technology of Polymers and Dyes, Department of Chemistry, Aristotle \\ University of Thessaloniki, GR-541 24 Thessaloniki, Greece; azamboulis@gmail.com (A.Z.); \\ dbic@chem.auth.gr (D.N.B.) \\ 2 AIMPLAS, Asociación de Investigación de Materiales Plásticos Y Conexas, Carrer de Gustave Eiffel, 4, \\ 46980 Valencia, Spain; mavalera@aimplas.es (M.A.V.); amangas@aimplas.es (A.M.) \\ * Correspondence: terzozoi@chem.auth.gr
}

check for updates

Citation: Terzopoulou, Z; Zamboulis, A.; Bikiaris, D.N.; Valera, M.A.; Mangas, A. Synthesis, Properties, and Enzymatic Hydrolysis of Poly(lactic acid)-co-Poly (propylene adipate) Block Copolymers Prepared by Reactive Extrusion. Polymers 2021, 13, 4121. https://doi.org/10.3390/ polym 13234121

Academic Editors: Nadia Lotti, Andreia F. Sousa and Incoronata Tritto

Received: 2 November 2021 Accepted: 22 November 2021 Published: 26 November 2021

Publisher's Note: MDPI stays neutral with regard to jurisdictional claims in published maps and institutional affiliations.

Copyright: (c) 2021 by the authors. Licensee MDPI, Basel, Switzerland. This article is an open access article distributed under the terms and conditions of the Creative Commons Attribution (CC BY) license (https:/ / creativecommons.org/licenses/by/ $4.0 /)$.

\begin{abstract}
Poly(lactic acid) (PLA) is a biobased polyester with ever-growing applications in the fields of packaging and medicine. Despite its popularity, it suffers from inherent brittleness, a very slow degradation rate and a high production cost. To tune the properties of PLA, block copolymers with poly(propylene adipate) (PPAd) prepolymer were prepared by polymerizing L-lactide and PPAd oligomers via reactive extrusion (REX) in a torque rheometer. The effect of reaction temperature and composition on the molecular weight, chemical structure, and physicochemical properties of the copolymers was studied. The introduction of PPAd successfully increased the elongation and the biodegradation rate of PLA. REX is an efficient and economical alternative method for the fast and continuous synthesis of PLA-based copolymers with tunable properties.
\end{abstract}

Keywords: poly(lactic acid); poly(propylene adipate); copolymers; biodegradable polymers; ring opening polymerization; reactive extrusion

\section{Introduction}

The negative effects of conventional petrochemical-based plastics on the environment, namely the accumulation of waste [1], marine litter, microplastics [2] and contribution to $\mathrm{CO}_{2}$ emissions, have raised concerns about the future of the planet. The most popular approach to minimize the problem, which is recycling, is only performed in less than $10 \%$ of the plastic waste (mainly mechanical recycling of poly(ethylene terephthalate)); the majority of it still ends up in landfills [3]. In addition, the COVID-19 pandemic had a profound effect on the increase of municipal and medical waste and disrupted waste management [4]. However, because of the unique characteristics of plastics and their integral role in modern society, their production, as well as waste accumulation, are expected to keep increasing [1].

Plastics are considered one of the world's most important environmental problems, which led to EU regulations that are designed to help transition to a sustainable plastics economy [5]. To reduce the negative impacts of plastics, various initiatives have been undertaken; the ban of single-use plastics, the regulation of plastic shopping bags, the promotion of the reduce-reuse-recycle approach and raising consumer awareness being the most prevalent ones. To fully transition to a sustainable future, the radical transformation of the plastics market towards biobased and biodegradable polymers is necessary [6]. Many biobased and/or biodegradable plastics with a wide variety of properties have been reported on a research level $[7,8]$, and some are being produced on a commercial scale $[9,10]$. Among them, poly(lactic acid) (PLA), a biobased, biocompatible, and compostable aliphatic polyester is one of the most produced and used biobased plastics in the world [11]. It is predominantly synthesized via the ring opening polymerization (ROP) of lactide, using 
organometallic catalysts [12]. PLA is processable with the typical extrusion, injection and blow moulding methods, and its properties can be tuned by changing the L- and D-lactic acid stereoisomer ratio that in turn tunes its crystallinity. Currently, it is used mainly as a packaging and biomedical material [6], and it is the most popular thermoplastic for fused filament fabrication (3D printing) filaments, a newer application that skyrocketed the demand for PLA [13]. The main limitations of PLA that restrict its applications are its inherent brittleness ( $<10 \%$ elongation) and its very slow degradation rate. Even though, for many years, and still to this day, PLA is referred to as biodegradable, it is practically only susceptible to industrial composting [14].

Some of the approaches to overcome the brittleness and slow degradation rate of PLA are copolymerization, blending with other polymers, and addition of plasticizers or fillers [15-19]. The most popular approach to tune the properties of PLA is the copolymerization of L- and D-isomers, and most commercially available PLA grades for packaging applications contain a small amount of the D-isomer [20]. Biomedical grade PLA is often copolymerized with glycolide, ethylene glycol, or monomethyl ether ethylene glycol towards random or block copolymers, respectively [21,22]. These comonomers are used mostly to tune the biodegradation rate and form amphiphilic copolymers. Other lactones have been used, such as $\varepsilon$-caprolactone [23]. When aliphatic polyester pre-polymers are used instead of their monomers in the ROP of PLA, they act as macroinitiators and block copolymers are obtained [24-26]. In contrast with PLA polymer blends, block copolymers can be partially miscible or weakly segregated, allowing the second component to act as a plasticizer [27]. In that case, the addition of compatibilizers such as chain extenders or coupling agents is not required.

Adipic acid (AdA) is considered the most important dicarboxylic acid by the International Energy Agency, because of its use in the synthesis of polyurethanes, polyamides, and its applications as a plasticizer, as well as in food additives and in the cosmetics industry. The production of biobased adipic acid is under development, and the currently known processes are both chemo-enzymatic (with glucose as precursor) and fermentation [28-30]. Aliphatic polyesters based on adipic acid and their copolymers are commercially available. The well-known biodegradable poly(butylene-adipate-co-terephthalate) (PBAT) finds applications in packaging and as a mulch film [31]. Poly(propylene adipate) (PPAd) was first synthesized in 2007 by the group of Bikiaris, and it had elongation at break $\sim 400 \%$ and tensile strength $\sim 11.5 \mathrm{MPa}$, with low glass transition, melting and cold crystallization temperatures $\left(\mathrm{T}_{\mathrm{g}}=-57^{\circ} \mathrm{C}, \mathrm{T}_{\mathrm{m}}=29^{\circ} \mathrm{C}, \mathrm{T}_{\mathrm{cc}}=-8^{\circ} \mathrm{C}\right)$ [32]. It also crystallizes quite fast due to the large number of methylene groups on its macromolecular chain $[33,34]$.

To incorporate fillers, additives or comonomers into PLA, reactive extrusion (REX) is commonly employed on an industrial scale [12]. Besides compounding, REX can be used to synthesize PLA from lactide in a continuous manner, using a twin-screw extruder [35-40]. This method is economically viable, requires very short reaction times (5-10 min), and is a continuous single-stage process $[35,41]$. The copolymers obtained by REX are very similar to those prepared with batch-type processes, but require a lot less time.

In this work, poly(propylene adipate) (PPAd) pre-polymer was synthesized with the two-stage melt polycondensation of AdA and 1,3-propanediol (1,3-PD) and used in the synthesis of PLA-co-PPAd copolymers for the first time via REX in a torque rheometer as a preliminary step for the scale-up of the process to continuous REX in a twin-screw extruder. The mass of PPAd in the formulation varied from 5 to $25 \mathrm{wt} \%$. Neat PLA from L-lactide (with $5 \%$ D-isomer) was also synthesized as a control. Two different reactions temperatures, namely $180{ }^{\circ} \mathrm{C}$ and $190{ }^{\circ} \mathrm{C}$ were tested. The resulting polymers were characterized by means of their physicochemical properties, including molecular weight determination, evaluation of thermal transition temperatures, tensile properties, hydrophilicity, and hydrolysis rate measurements. 


\section{Materials and Methods}

\subsection{Materials}

Adipic acid (AdA) (purity >99.5\%) and 1,3-propanediol (1,3-PD) (purity $>99.6 \%$ ) were purchased from Fluka (Steinheim, Germany). Titanium butoxide (Ti(OBu) $)_{4}$, purity: $>97.0 \%$ ), was purchased from Sigma Aldrich Chemical Co (Steinheim, Germany). L-Lactide (LA) Purlact B3 (purity 99\% w/w, stereochemical purity in L-isomer 95\% (w/w) was purchased from Corbion N.V. (Gorinchem, The Netherlands) and Tin(II) 2-ethylhexanoate (Sn(Oct)2, purity $>92.5 \%$ ) from Merck KGaA, (Darmstadt, Germany).

\subsection{Synthesis of Aliphatic Polyesters}

\subsubsection{Synthesis of Poly(propylene adipate) (PPAd)}

The classic two-stage melt polycondensation method was used for the synthesis of PPAd aliphatic polyester [42-44]. In the first stage (esterification), AdA and 1,3-PD in a $1 / 1.1$ molar ratio were charged into the reaction tube in the presence of $400 \mathrm{ppm}$ of $\mathrm{Ti}(\mathrm{OBu})_{4}$. The reaction mixture was heated at $180^{\circ} \mathrm{C}$, under $\mathrm{N}_{2}$ atmosphere and continuous stirring. The reaction lasted until the theoretical amount of $\mathrm{H}_{2} \mathrm{O}$ produced during the reaction was collected $(3.5 \mathrm{~h})$. In the second stage (polycondensation), vacuum (5.0 Pa) was slowly applied to minimize the creation of foam and to avoid PPAd oligomer sublimation, and the polycondensation procedure was carried out at $230{ }^{\circ} \mathrm{C}$ for $15 \mathrm{~min} . \overline{M_{n}}=6300 \mathrm{~g} / \mathrm{mol}(\mathrm{GPC})$.

\subsubsection{Synthesis of Poly(l-lactide)-co-poly(propylene adipate) Copolymers}

PLA and its copolymers with PPAd were prepared by REX in a Brabender ${ }^{\circledR}$ PlastiCorder $^{\circledR}$ Lab-Station torque rheometer. The ROP of lactide was catalysed by $\mathrm{Sn}(\mathrm{Oct})_{2}$ in a lactide/Sn(Oct) 2 molar ratio 1000/1. Triphenyl phosphine (TPP) was used as co-catalyst, in equimolar amount to $\mathrm{Sn}(\mathrm{Oct})_{2}$ [38]. The catalyst system was added as a solution in dry toluene. PPAd (diol) was added as initiator for the ROP of lactide to obtain PLA-co-PPAd copolymers. Blank samples without an initiator (ROP initiated by traces of $\mathrm{H}_{2} \mathrm{O}$ ) were also prepared. The polymerization was carried out at temperatures of $180{ }^{\circ} \mathrm{C}$ and $190{ }^{\circ} \mathrm{C}$ in the mixing chamber, with a $100 \mathrm{rpm}$ screw speed. A small stream of dry $\mathrm{N}_{2}$ was circulated to minimize the presence of air in the mixing chamber. The premix of lactide/PPAd/catalyst solution was fed to the rheometer at $t=0$. Motor torque ( $\alpha$ viscosity) and temperature were monitored vs. time during the polymerization. The samples prepared are listed in Table 1 ; where 180 and 190 corresponds to the reaction temperature and the ratios 95/5, 85/15 and $75 / 25$ to the feed weight ratios of lactide and PPAd, respectively.

Table 1. List of the homopolymers and copolymers prepared.

\begin{tabular}{c}
\hline Sample Name \\
\hline PLA 180 \\
\hline PLA-PPAd 95/5 180 \\
\hline PLA-PPAd $85 / 15180$ \\
\hline PLA-PPAd $75 / 25180$ \\
\hline PLA 190 \\
\hline PLA-PPAd 95/5 190
\end{tabular}

\subsubsection{Characterization}

The molecular weight of the materials was determined using gel permeation chromatography (GPC) with a Waters 600 high-performance liquid chromatographic pump, Waters Ultrastyragel columns HR-1, HR-2, HR-4E, HR-4 and HR-5, and a Shimadzu RID$10 \mathrm{~A}$ refractive index detector. For the calibration, 9 polystyrene (PS) standards of molecular weight between 2.5 and $900 \mathrm{~kg} / \mathrm{mol}$ were employed. The prepared solutions had a concentration of $15 \mathrm{mg} / \mathrm{mL}$, the injection volume was $100 \mu \mathrm{L}$ and the total elution time was $50 \mathrm{~min}$. The oven temperature was $40^{\circ} \mathrm{C}$. 
Nuclear magnetic resonance (NMR) spectra were recorded in deuterated chloroform for the structural study of monomer and polymer, respectively. An Agilent 500 spectrometer was utilized (Agilent Technologies, Santa Clara, CA, USA), at room temperature. Spectra were calibrated using the residual solvent peaks.

The morphology of cryofractured cross sections of the samples was studied with a JEOL (Tokyo, Japan) JSM 7610F field emission scanning electron microscope (SEM) operating at $5 \mathrm{kV}$.

Differential scanning calorimetry (DSC) analysis was performed using a PerkinElmer Pyris Diamond DSC differential scanning calorimeter (Solingen, Germany) calibrated with pure indium and zinc standards. The system included a PerkinElmer Intracooler 2 (Solingen, Germany) cooling accessory. Samples of $5 \pm 0.1 \mathrm{mg}$ sealed in aluminium pans were used to test the thermal behavior of the polymers. Crystallinity degree $\left(X_{c}\right)$ was calculated with equation $\mathrm{X}$ :

$$
\mathrm{X}_{\mathrm{c}}(\%)=\left(\frac{\Delta H_{\mathrm{m}}-\Delta H_{\mathrm{cc}}}{\Delta H_{\mathrm{f}}^{0}-\frac{1-\mathrm{wt} \% \text { PPAd }}{100}}\right) \times 100
$$

where $\Delta H_{\mathrm{m}}, \Delta H_{\mathrm{cc}}, \Delta H_{\mathrm{f}}^{0}$ are the experimental melting enthalpy, cold-crystallization enthalpy and the theoretical heat of fusion of $100 \%$ crystalline PLA $\left(\Delta H_{f}^{0}=93 \mathrm{~J} / \mathrm{g}\right)$, respectively.

X-ray Diffraction (XRD) measurements of the polymers and copolymers were performed over the $2 \theta$ range of 5 to $60^{\circ}$, with steps of $0.05^{\circ}$, scanning speed $1.5 \mathrm{deg} / \mathrm{min}$, using a MiniFlex II XRD system from Rigaku Co. (Tokyo, Japan) with Cu Ka radiation $(\lambda=0.154 \mathrm{~nm})$.

Infrared (IR) spectra were recorded with a Cary 670 (Santa Clara, CA, USA), Agilent Technologies, equipped with a diamond attenuated total reflectance accessory, ATR, model GladiATR, Pike Technologies. The spectra were recorded in the range $4000-400 \mathrm{~cm}^{-1}$ with 32 scans and resolution $4 \mathrm{~cm}^{-1}$.

Tensile tests were performed using an Instron 3344 dynamometer (Norwood, MA, USA), in accordance with ASTM D638 using a crosshead speed of $5 \mathrm{~mm} / \mathrm{min}$. Dumbbell-shaped tensile test specimens (central portions $5 \mathrm{~mm} \times 0.5 \mathrm{~mm}$ thick, $22 \mathrm{~mm}$ gauge length) were prepared by compression moulding in a thermopress at $180^{\circ} \mathrm{C}$, cooled rapidly and cut in a Wallace cutting press. At least five measurements were conducted for each sample, and the results were averaged to obtain the mean values of Young's modulus, tensile strength at yield and breakpoint, and elongation at break. A student's T-test was used to determine the statistical significance.

Water contact angle was measured with an Ossila contact angle goniometer L2004A1 at room temperature $\left(25^{\circ} \mathrm{C}\right)$. Contact angle was measured by gently placing a water droplet $(5 \mu \mathrm{L})$ on the surface of films of the samples prepared by compression moulding. At least three measurements were performed, and the mean value is reported. A one-way ANOVA test with post hoc Bonferroni correction was performed to determine the effect of the presence of PPAd on the water contact angle of PLA. The software used was IBM SPSS Statistics (IBM, 27). A $p$-value $\leq 0.05$ was considered statistically significant.

For the enzymatic degradation testing, thin films prepared by compression moulding (thickness $0.8-1 \mathrm{~mm}$ ) were cut in squares with dimensions $\sim 1.5 \mathrm{~cm} \times 1.5 \mathrm{~cm}$ and were placed in test tubes containing $10 \mathrm{~mL}$ phosphate buffer solution (pH 7.4) with $0.01 \mathrm{mg} / \mathrm{mL}$ lipase from Pseudomonas cepacia and $0.1 \mathrm{mg} / \mathrm{mL}$ lipase from Rhizopus oryzae. The flasks were then incubated at $36.6 \pm 1{ }^{\circ} \mathrm{C}$ in an oven for several days while the media were replaced every 3 days. After a specific period of incubation (every 5 days), the samples were removed from the flasks, washed with distilled water, dried under vacuum, and weighed until they remained at a constant weight. The degree of enzymatic hydrolysis was estimated from the mass loss of the samples. Blank incubations were also carried out with 
the samples in the same buffer without enzyme addition. The degree of biodegradation was estimated by the sample weight loss, according to the following equation:

$$
\text { Mass loss } \%=\frac{W_{0}-W_{i}}{W_{o}}
$$

Each sample was hydrolyzed in triplicate and the mean value was calculated.

\section{Results and Discussion}

\subsection{Synthesis of PLA-co-PPAd Copolymers}

The polymerization of PLA was carried out initiated by $\mathrm{H}_{2} \mathrm{O}$ traces present in raw lactide. The rheograms obtained at $180^{\circ} \mathrm{C}$ and $190^{\circ} \mathrm{C}$ are shown in Figure 1a.
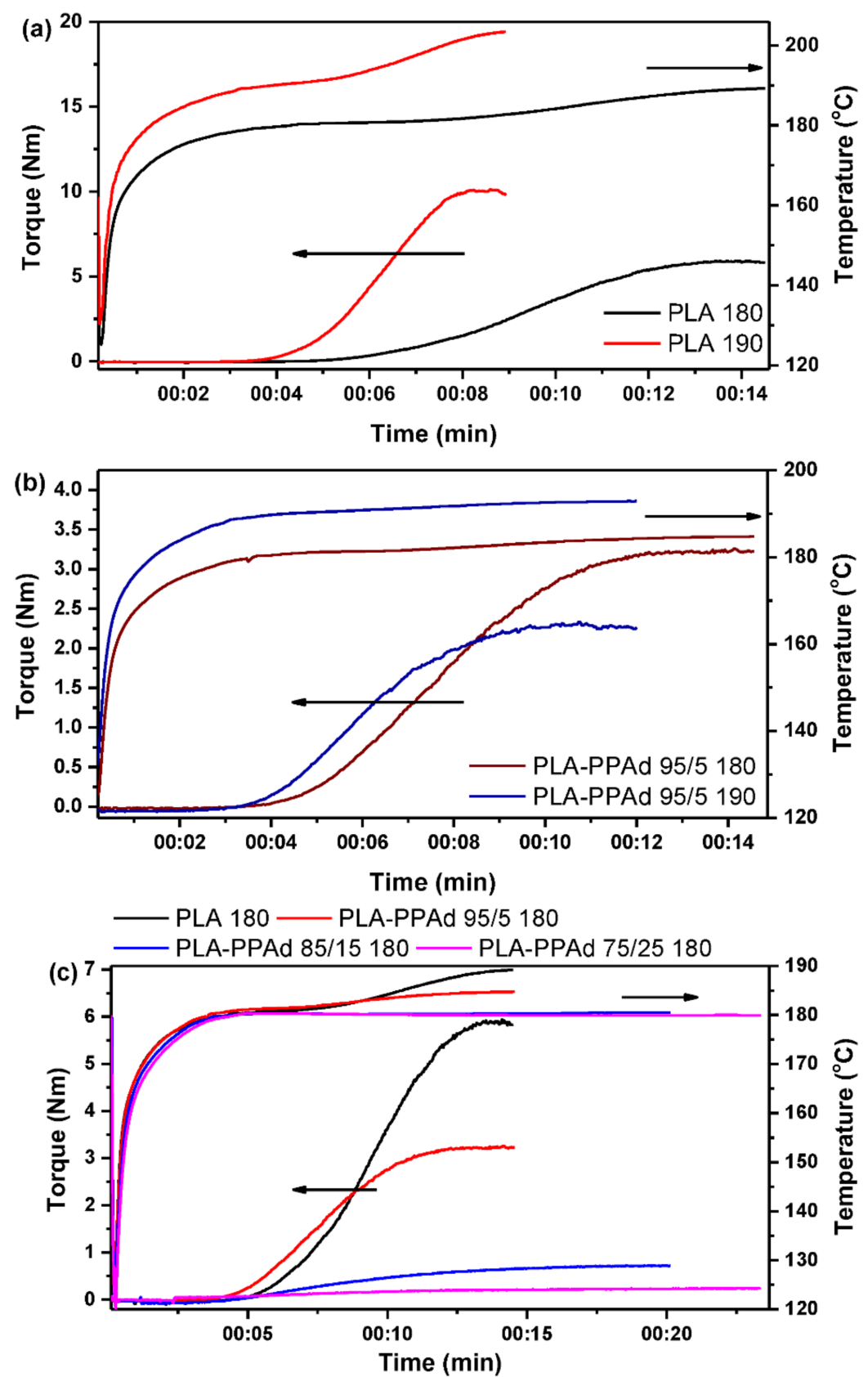

Figure 1. Torque/temperature curves for (a) ROP of L-lactide at $180{ }^{\circ} \mathrm{C}$ and $190{ }^{\circ} \mathrm{C}$, (b) ROP of PLA initiated by PPAd ( $5 \mathrm{wt} \%$ ) at $180^{\circ} \mathrm{C}$ and $190^{\circ} \mathrm{C}$, (c) ROP of PLA initiated by PPAd at $5 \mathrm{wt} \%, 15 \mathrm{wt} \%$ and $25 \mathrm{wt} \%$ at $180^{\circ} \mathrm{C}$. 
At $190^{\circ} \mathrm{C}$, the ROP of lactide was faster in comparison to $180^{\circ} \mathrm{C}$, reaching the maximum torque at $8.5 \mathrm{~min}$ and $14 \mathrm{~min}$, respectively. In addition, the torque (which is proportional to molecular weight or viscosity) was also higher at higher temperature (10.1 Nm at $190^{\circ} \mathrm{C}$ vs. $5.9 \mathrm{Nm}$ at $180^{\circ} \mathrm{C}$ ). However, depolymerization started right after the torque peak was reached, when the mixing chamber temperature was fixed at $190^{\circ} \mathrm{C}$, because the actual melt temperature increased above $200{ }^{\circ} \mathrm{C}$.

Following the same procedure, PLA-co-PPAd copolymers were prepared at $180{ }^{\circ} \mathrm{C}$ and $190^{\circ} \mathrm{C}$ using $5 \mathrm{wt} \%$ of PPAd as macroinitiator for the ROP of L-lactide.

For PLA-PPAd $95 / 5$, the polymerization was faster at $190^{\circ} \mathrm{C}$, reaching stable torque after $11 \mathrm{~min}$, whereas at $180^{\circ} \mathrm{C}$ torque stability was reached after $14 \mathrm{~min}$ (Figure 1b). However, despite the faster polymerization at higher temperature, the maximum torque ( $\alpha \mathrm{Mw})$ was achieved at $180^{\circ} \mathrm{C}$ ( $3.3 \mathrm{Nm}$ versus $2.3 \mathrm{Nm}$ respectively). Therefore, despite the faster polymerization, the temperature for the polymerization of the PLA-co-PPAd copolymers was fixed at $180^{\circ} \mathrm{C}$. The torque-temperature curves of all the polymers prepared at $180^{\circ} \mathrm{C}$ are shown in Figure 1c.

As PPAd acts as initiator of the ROP of lactide, the higher content of initiator results in faster initiation of the polymerization reaction; however, the maximum Torque (viscosity) is lower due to a larger number of initiation points.

It must be highlighted that at $5 \mathrm{wt} \%$ of PPAd, the time required for torque stabilization is similar to blank PLA (12-14 $\mathrm{min}$ ), and viscosity and melt strength of the PLA-co-PPAd is still good for polymer transformation, for example, for injection moulding applications.

For higher PPAd contents, the required residence time to achieve torque stabilization was $>20 \mathrm{~min}$ and resulted in PLA-co-PPAd copolymers with low viscosity and melt strength. Those copolymers would have poor processability by either extrusion or injection moulding technologies; however, they can find applications as base resins in formulations of hot melt adhesives where high viscosity or molecular weight is not required.

\subsection{Spectroscopic Characterization}

The signals of both PLA (quadruplet peak at $5.16 \mathrm{ppm}$ and double peak at $1.58 \mathrm{ppm}$ ) and PPAd (triplet at $4.14 \mathrm{ppm}$, a broad peak at $2.03 \mathrm{ppm}$, a multriplet at $1.96 \mathrm{ppm}$ and a multiple peak at $1.66 \mathrm{ppm}$ ) are visible in the ${ }^{1} \mathrm{H}$ NMR spectra of the PLA-co-PPAd copolymers (Figures $2 \mathrm{a}$ and $3 \mathrm{a}$ ). Additionally, traces of unreacted lactide can be observed at $5.03 \mathrm{ppm}$. In the ${ }^{13} \mathrm{C}$ NMR spectra (Figures $2 \mathrm{~b}$ and $3 \mathrm{~b}$ ), among the other expected resonance signals, the peaks of the two ester carbonyls are clearly visible at 169.5 ppm (PLA) and $173.1 \mathrm{ppm}$ (PPAd), which further confirms successful polymerization.

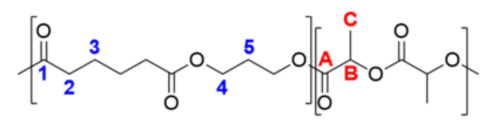

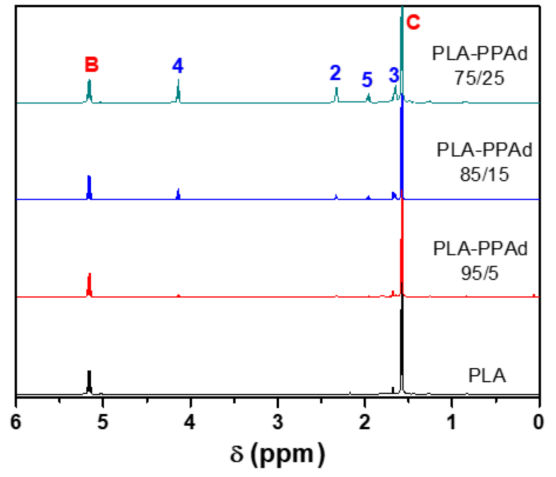

(a)

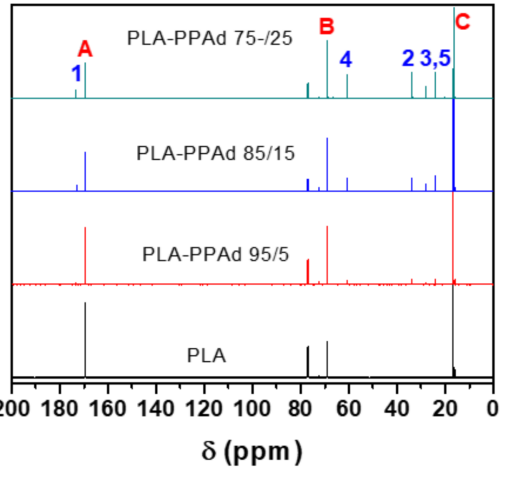

(b)

Figure 2. (a) ${ }^{1} \mathrm{H}$ NMR and (b) ${ }^{13} \mathrm{C}$ NMR spectra of the samples prepared at $180{ }^{\circ} \mathrm{C}$. 


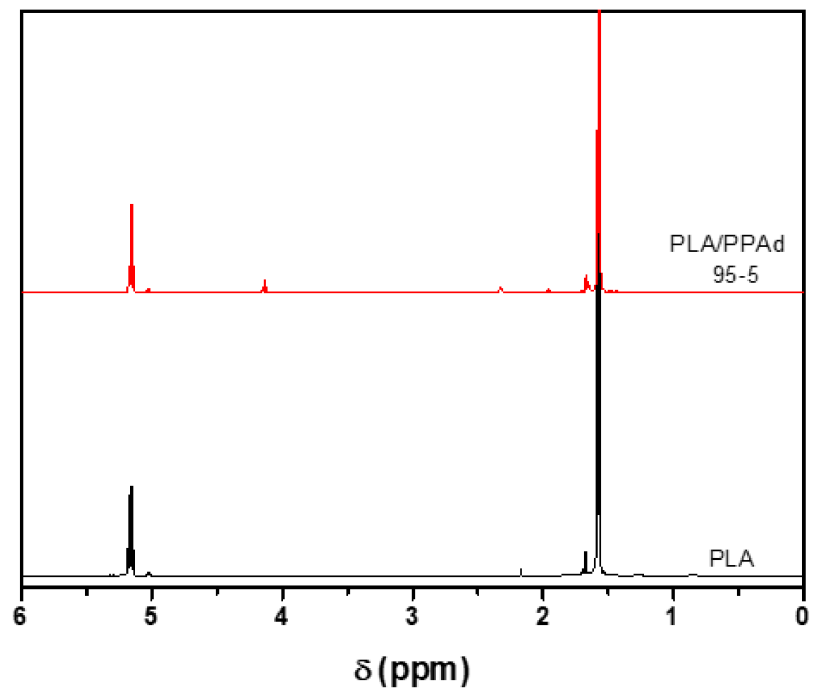

(a)

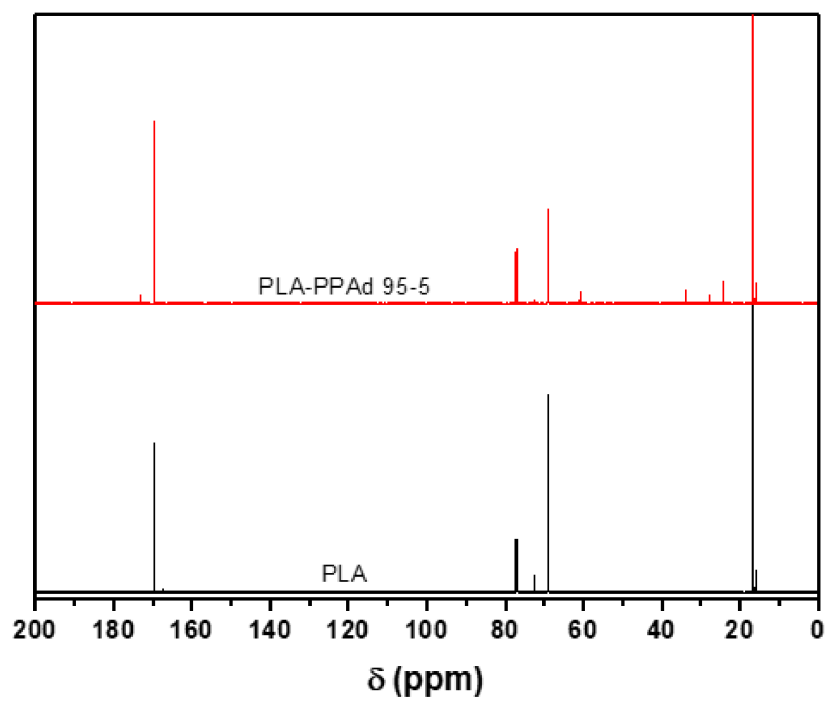

(b)

Figure 3. (a) ${ }^{1} \mathrm{H}$ NMR and (b) ${ }^{13} \mathrm{C}$ NMR spectra of the samples prepared at $190{ }^{\circ} \mathrm{C}$.

The composition of the copolymers was calculated by comparing the integrations of peaks $\mathrm{B}$ and 4 of the ${ }^{1} \mathrm{H}$ NMR spectra (Figure 2a). It was found to be in complete agreement with the feed ratio (Table 2). Finally, NMR spectra can give some insight about the microstructure of the synthesized copolymers. With a closer look, several small peaks can be observed between 4.1 and 4.4 ppm in PLA-PPAd 85/15 and PLA-PPAd 75/25. One of them was attributed to the $\mathrm{CH}_{2} \mathrm{OC}(\mathrm{O})$ methylene group of a 1,3-PD unit, which is adjacent to a PLA ester, confirming successful copolymerization. Due to their low intensity and some overlapping, the peak could not be integrated to calculate the randomness of the copolymers. Nevertheless, judging from its low intensity, we can safely conclude that the copolymers exhibit a blocky structure with long PLA sequences.

Table 2. Unreacted lactide and comonomer molar ratios calculated by NMR.

\begin{tabular}{ccccccc}
\hline Temperature & & & $\mathbf{1 8 0}{ }^{\circ} \mathbf{C}$ & \multicolumn{1}{c}{$\mathbf{1 9 0}^{\circ} \mathbf{C}$} \\
\hline Sample & PLA & PLA-PPAd 95/05 & PLA-PPAd 85/15 & PLA-PPAd 75/25 & PLA & PLA-PPAd 95/05 \\
\hline Unreacted lactide (\%) & 5.8 & 5.8 & 7.1 & 6.7 & 5.6 & 5.8 \\
\hline PLA-PPAd ratio & - & $94 / 06$ & $84 / 16$ & $74 / 26$ & - & $94 / 06$ \\
\hline
\end{tabular}

The ATR spectra of PPAd, PLA, and their copolymers are shown in Figure S1a. PLA shows characteristic IR peaks at $3488 \mathrm{~cm}^{-1}$ assigned to O-H bending, at $2994-2944 \mathrm{~cm}^{-1}$ of $\mathrm{C}-\mathrm{H}$ stretching, at $1747 \mathrm{~cm}^{-1}$ caused by $\mathrm{C}=\mathrm{O}$ stretching, at $1452 \mathrm{~cm}^{-1}$ of $-\mathrm{CH}_{3}$ asymmetric bending, at $1182 \mathrm{~cm}^{-1}$ and $1040 \mathrm{~cm}^{-1}$ because of the stretching of the $-\mathrm{C}-\mathrm{O}-\mathrm{C}-$ groups [45]. The IR spectra of amorphous and crystalline PPAd have been analyzed in depth in the past [34], and the spectrum recorded here shows the same peaks. While most peaks overlap with those of PLA, two of them witness the presence of the adipic segment; the $\mathrm{CH}_{2}$ bending at $1467 \mathrm{~cm}^{-1}$ and the $\mathrm{C}-\mathrm{O} / \mathrm{C}-\mathrm{C}$ stretch at $1255 \mathrm{~cm}^{-1}$. Additionally, the peak of the carbonyl group of PPAd appears at $1720 \mathrm{~cm}^{-1}$. The spectra of the copolymers do not show any significant differences from the spectrum of PLA. After closer examination of the carbonyl's region Figure S1(b), the peak of the copolymers is broader than the PLA homopolymer. A shoulder appears on the peak of the sample PLA-PPAd 85/15 180, and it finally becomes double for $25 \%$ PPAd. The emerging of the double carbonyl IR peak is evidence of the presence of PPAd segments in the copolymers. 


\subsection{Molecular Weight Determination}

The molecular weight and polydispersity index (PDI) of all the polymers prepared were measured by GPC. The resulting chromatographs are shown in Figure S2 and the values in Table 3. All chromatographs have only one distribution curve, witnessing the purity of the materials and the successful introduction of the PPAd oligomer in the PLA macromolecular chains. The $\overline{M_{n}}$ of PLA 180 was $75,600 \mathrm{~g} / \mathrm{mol}$, which is comparable to commercially available injection moulding grade PLA, while for PLA 190 it was 103,400 g/mol, similar to commercially available PLA appropriate for film production [46]. Similar $\overline{M_{n}}$ values that were reported in the literature $[23,36,40]$. When prepared in a melt polycondensation apparatus, with reaction times $>2 \mathrm{~h}$, PLA-co-PPAd copolymers had $\overline{M_{n}}=47,700$ and $53,700 \mathrm{~g} / \mathrm{mol}$ for PPAd content $15 \mathrm{wt} \%$ and $31 \mathrm{wt} \%$ respectively [47], which are very close to the values obtained by REX, for much smaller reaction times.

Table 3. Molecular weight and PDI (GPC) of PLA and the copolymers with PPAd.

\begin{tabular}{ccccc}
\hline Sample & $\overline{\boldsymbol{M}_{\boldsymbol{n}}}(\mathbf{g} / \mathbf{m o l})$ & $\overline{\boldsymbol{M}_{\boldsymbol{w}}}(\mathbf{g} / \mathbf{m o l})$ & $\overline{\boldsymbol{M}_{\boldsymbol{p}}}(\mathbf{g} / \mathbf{m o l})$ & PDI \\
\hline PLA 180 & 75,600 & 119,700 & 103,500 & 1.58 \\
PLA-PPAd 95/5 180 & 63,300 & 94,100 & 88,800 & 1.48 \\
PLA-PPAd 85/15 180 & 41,200 & 55,000 & 54,800 & 1.33 \\
PLA-PPAd 75/25 180 & 29,400 & 39,300 & 38,500 & 1.34 \\
PLA 190 & 103,400 & 161,300 & 134,200 & 1.56 \\
PLA-PPAd 95/5 190 & 60,100 & 88,200 & 80,300 & 1.46 \\
PPAd & 6300 & 11,340 & 10,800 & 1.8 \\
\hline
\end{tabular}

$\overline{M_{\mathrm{n}}}$ : Number Average Molecular Weight, $M_{\mathrm{w}}$ : Weight Average Molecular Weight, $M_{\mathrm{p}}$ : peak maximum molecular mass, PDI: polydispersity index.

While PLA synthesized at $190{ }^{\circ} \mathrm{C}$ has higher molecular weight than when synthesized at $180^{\circ} \mathrm{C}$, the first copolymer that was tested (PLA-PPAd 95/5) had a better molecular weight when the ROP took place at $180^{\circ} \mathrm{C}$. In agreement with the motor torque monitoring during reactive extrusion, the molecular weight of the samples decreases after the addition of PPAd, and with increasing the PPAd content. The free hydroxyl groups of the PPAd oligomers act as a $\mathrm{co}$-initiator for the ROP, resulting in the observed smaller molecular weight values.

ROP is a propagation process of cyclic monomers. The process can be initiated by ions, and the ROP mechanisms can be anionic, cationic, or coordination-insertion [48]. The most common catalyst system utilized for lactide polymerization is $\mathrm{Sn}(\mathrm{Oct})_{2}$ with the addition of an initiator. $\mathrm{Sn}(\mathrm{Oct})_{2}$ catalyzes the ROP via a coordination-insertion mechanism (Scheme 1) [49]. Traces of water are also enough to initiate the ROP of lactide [49]. While $\mathrm{Sn}(\mathrm{Oct})_{2}$ promotes fast polymerization, it also causes undesirable inter- and intramolecular transesterification reactions that ultimately lead to low molecular weight.

TPP is a Lewis base that is used as an initiator and increases the polymerization rate of lactide and when combined with equimolar amounts of $\mathrm{Sn}(\mathrm{Oct})_{2}$; it allows for reaching an acceptable balance between propagation and depolymerization rates, essential for the ROP of lactide in an extruder $[37,38]$. Additionally, it leads to products with a narrower size distribution and without racemization reactions [38]. This is believed to occur because the coordination of the nucleophilic TPP on the metal atom polarizes the generated metal alkoxide, thus making the insertion of the monomer into the metal alkoxide bond of the initiator easier.

When adding the PPAd oligomers in the reaction mixture, their hydroxyl and carboxyl end groups are expected to participate in the reaction. By increasing the concentration of hydroxyls, the number of initiation sites is increased, resulting in more inactive PLA chains and fewer active tin alkoxide species, ultimately reducing the molecular weight [37]. Therefore, the larger the quantity of PPAd added, the smaller the molecular weight. While hydroxyls do not significantly affect monomer conversion, but do reduce the molecular weight, carboxyl end groups are expected to decelerate the reaction. PPAd reduced the 
molecular weight of PLA when the copolymers were prepared by melt polycondensation as well [47].

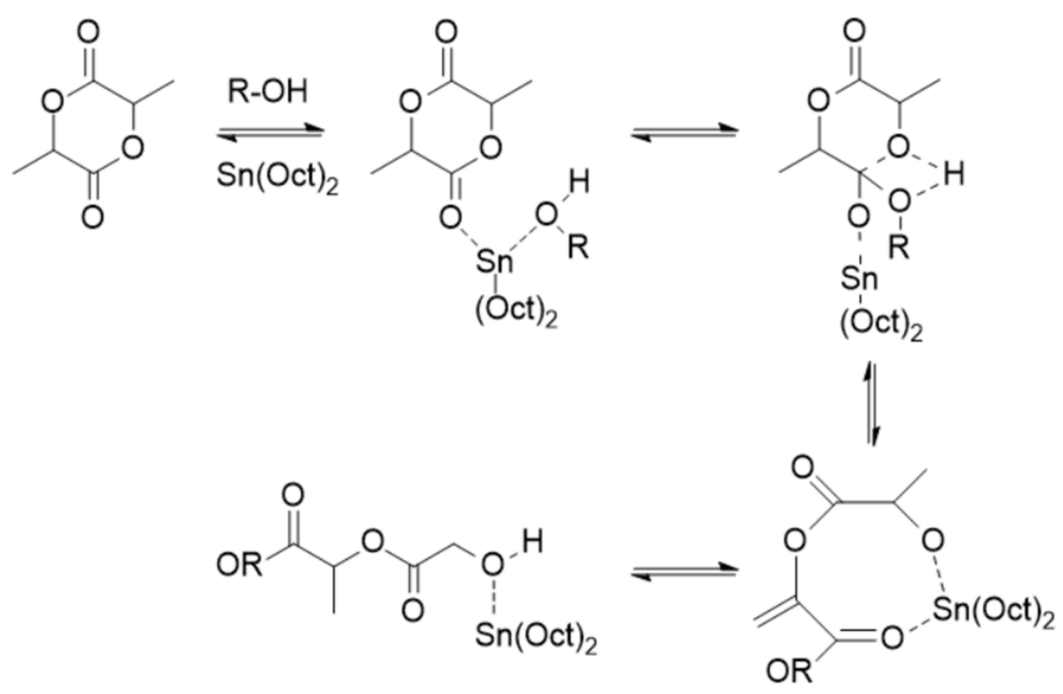

Scheme 1. Coordination-insertion mechanism of the ROP of lactide using Tin(II) octoate [50].

\subsection{Scanning Electron Microscopy (SEM)}

One method to investigate whether two polymers formed blends is to observe their cryofractured surfaces. In polymer blends, two distinct phases can usually be identified, with phase separation present when the different components are incompatible or immiscible. In the SEM micrographs of Figure S3, no evidence of a second phase exists on the surfaces of the PLA-co-PPAd copolymers with PPAd content up to $15 \mathrm{wt} \%$. The surface of PLA-PPAd 75/25 (Figure S3d) shows evidence of a second phase which could be PPAd, in the form of spherical particles, that are fully embedded in the PLA matrix. Lack of phase separation also supports the NMR conclusion that the materials are not blends, but copolymers.

\subsection{Thermal Properties and Crystallinity}

The DSC traces of PLA and its copolymers with PPAd are presented in Figure 4. The 1st heat corresponds to the as-received materials, which was followed by cooling with rate $10^{\circ} \mathrm{C} / \mathrm{min}$, a 2nd heating step, quenching, and finally re-heating of the quenched sample to obtain the glass transition $\left(\mathrm{T}_{\mathrm{g}}\right)$. All heating steps were performed with a rate of $20^{\circ} \mathrm{C} / \mathrm{min}$.

PPAd (Figure 4a) was received semicrystalline, as witnessed by its melting during the 1st heating scan. Its melting point $\left(\mathrm{T}_{\mathrm{m}}\right)$ was observed at $41{ }^{\circ} \mathrm{C}$, and its $\mathrm{T}_{\mathrm{g}}$ after quenching was $-57^{\circ} \mathrm{C}$. These values are consistent with previous reports $[33,34,47,51-53]$. The quenched PPAd also showed cold crystallization at $\mathrm{T}_{\mathrm{cc}}=6.8^{\circ} \mathrm{C}$ and melt crystallization at $\mathrm{T}_{\mathrm{C}}=-10.6^{\circ} \mathrm{C}$. PPAd exhibited a multiple melting behavior, since a secondary melting peak is recorded in its reheating scans at about $30^{\circ} \mathrm{C}$, right after the end of cold crystallization. This phenomenon has been observed before for PPAd [33] and is attributed to the melting of less perfect crystallites that did not have enough time to melt and recrystallize. 

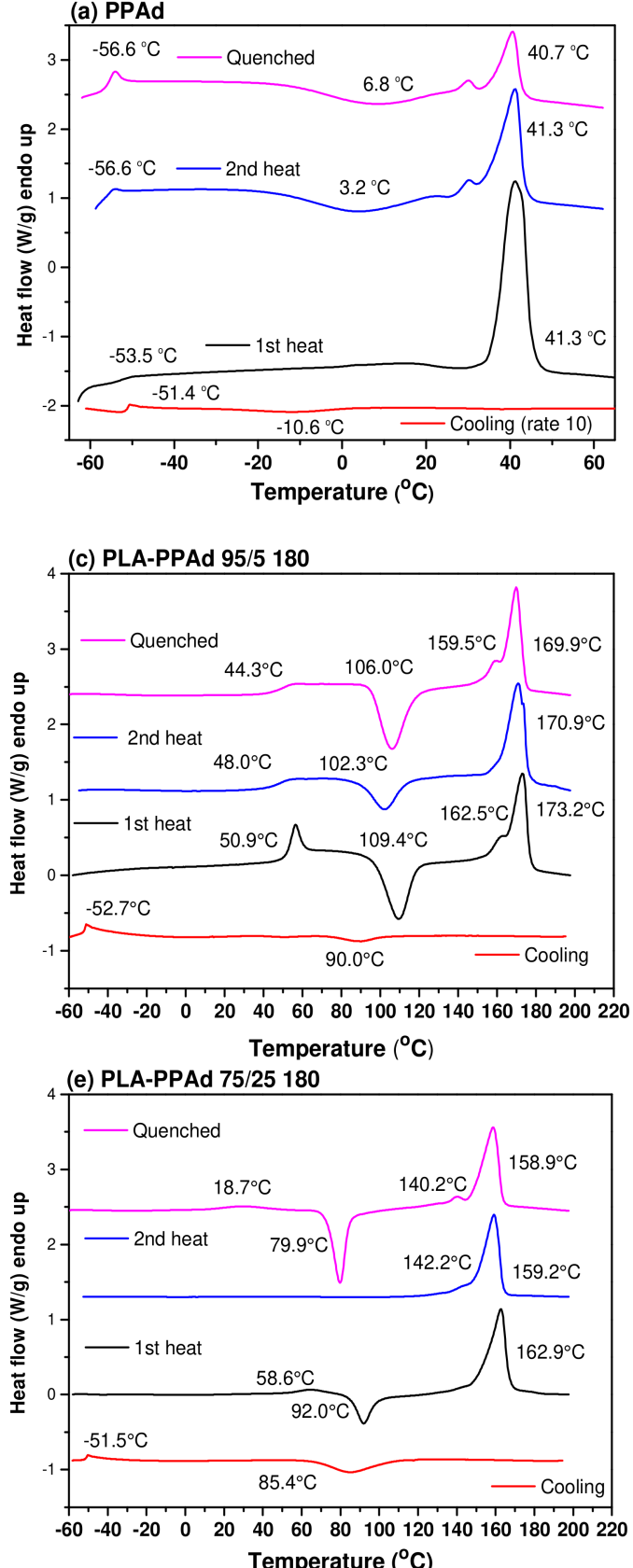
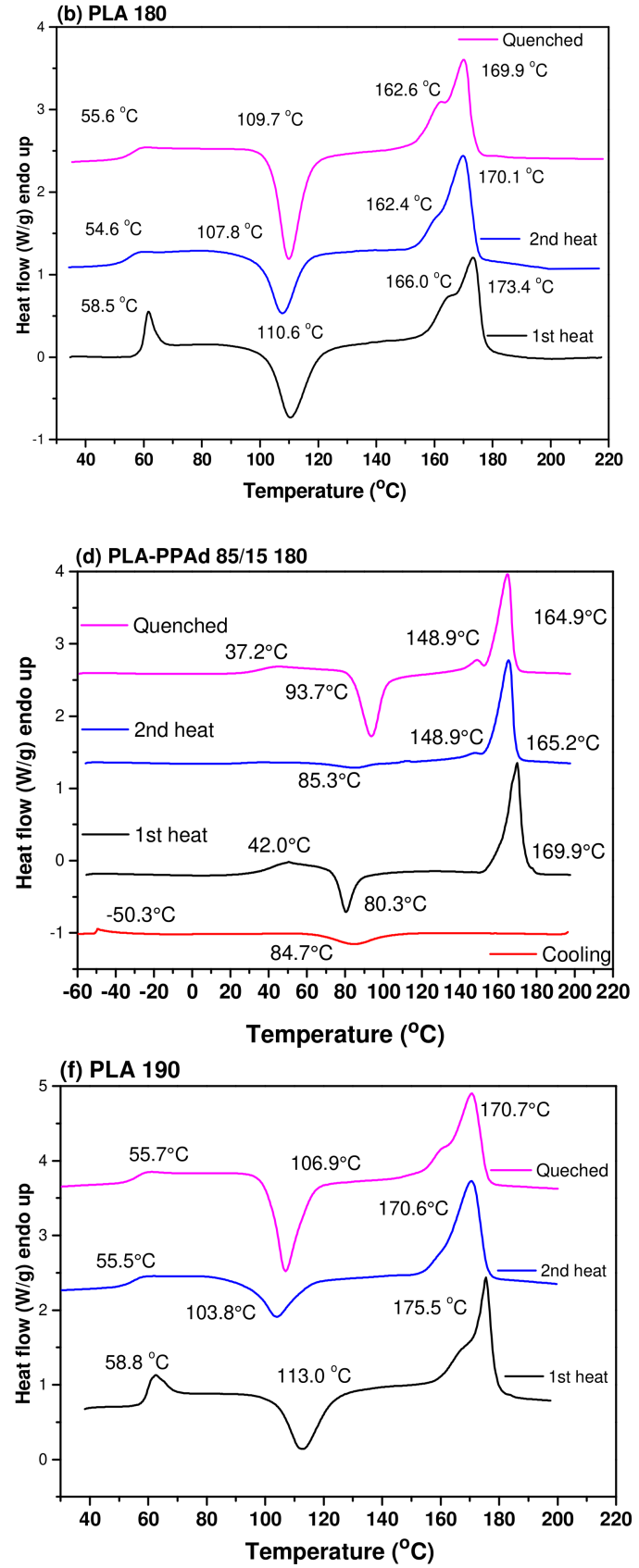

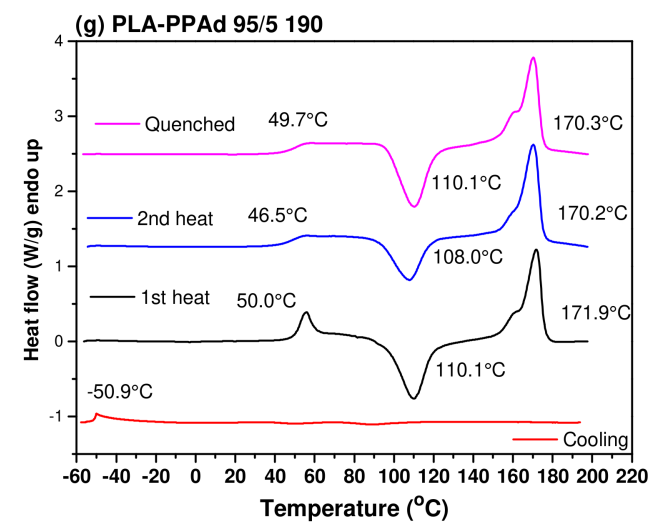

Figure 4. DSC traces of (a) PPAd, (b) PLA 180, (c) PLA 190, (d) PLA-PPAd 95/5 180, (e) PLA-PPAd 95/5 190, (f) PLA-PPAd 85/15 180, (g) PLA-PPAd 75/25 180. 
The DSC traces of PLA 180 (Figure 4b) show the glass transition, cold crystallization and multiple melting behavior in the common temperature ranges for PLA of medium molecular weight $[54,55]$. The $\mathrm{T}_{\mathrm{g}}$ of the melt-quenched PLA was observed at $55.6{ }^{\circ} \mathrm{C}$; it crystallizes during heating with a peak at $\mathrm{T}_{\mathrm{CC}}=109.7^{\circ} \mathrm{C}$ and the formed crystals partially melted at $162.2{ }^{\circ} \mathrm{C}$, and finally at $169.9{ }^{\circ} \mathrm{C}$, where the main melting endotherm is positioned. Multiple melting of PLA is ascribed to crystal reorganization during heating, and it is affected by the crystallization temperature [49]. The as-received PLA had a crystallinity of about $15 \%$, as calculated by Equation (1); however, it did not crystallize significantly during cooling with the applied rate. After the introduction of PPAd, the DSC curves remain similar to those of neat PLA (Figure 4c-e), with all copolymers retaining the semicrystalline character. Significant shifting of the peak temperatures is, however, observed. Neither melting, crystallization peaks nor glass transition that might arise from PPAd moieties exclusively exist. In contrast, blends of PLA with PPAd prepared by solution mixing showed two melting peaks that correspond to each polymer, proving their immiscibility [49].

The effect of PPAd content on the characteristic thermal transitions of PLA, deducted from the DSC curves, is presented in Figure $5 . T_{c c}, T_{m}$ and $T_{g}$ were obtained from the heating of the melt-quenched samples with a rate of $20^{\circ} \mathrm{C} / \mathrm{min}$, and the $\mathrm{T}_{\mathrm{C}}$ from the cooling run with rate $10^{\circ} \mathrm{C} / \mathrm{min}$. $\mathrm{T}_{\mathrm{cc}}, \mathrm{T}_{\mathrm{m}}$ and $\mathrm{T}_{\mathrm{g}}$ decreased by increasing the PPAd content. PPAd both reduces the molecular weight and acts as a plasticizer to PLA, which results in the decrease of the $T_{g}$ and $T_{m}$. In contrast with neat PLA, which crystallized insignificantly during cooling with the applied rate, all copolymers showed detectable melt crystallization peaks at around $85-90{ }^{\circ} \mathrm{C}$, which may be a result of the lower molecular weight of the copolymers, as well as the mobility of the aliphatic macromolecular chains of PPAd.

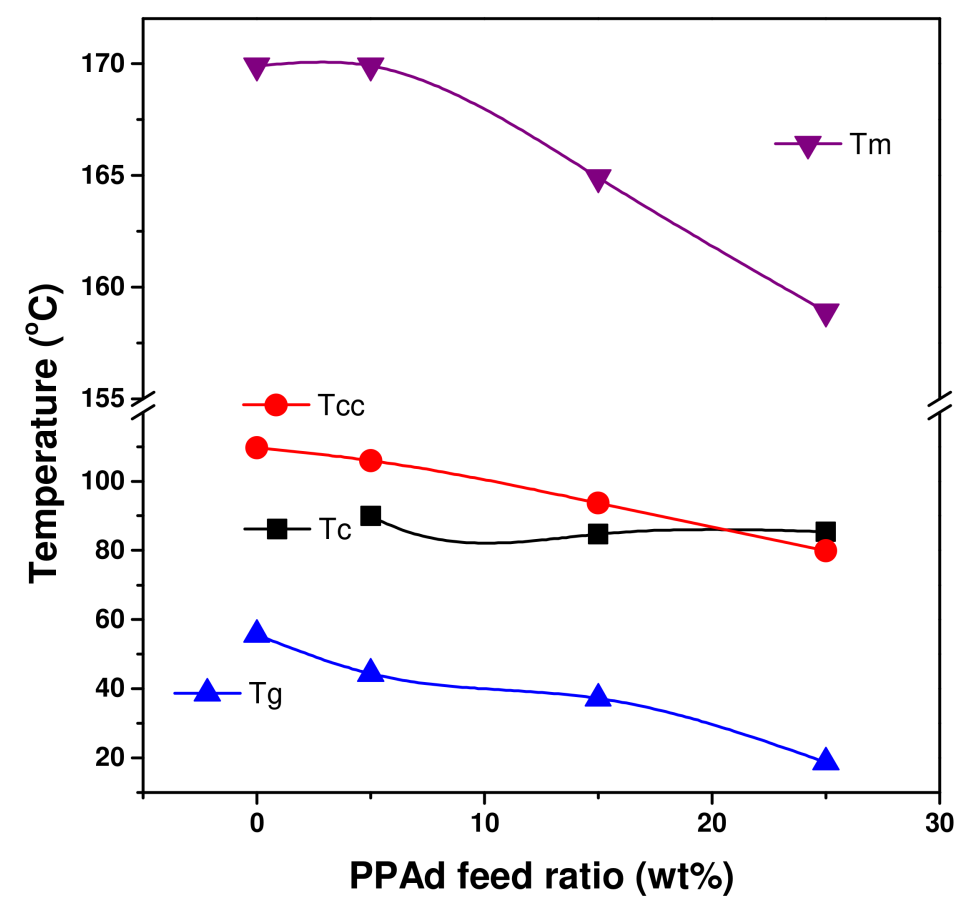

Figure 5. Effect of PPAd content on the thermal transition temperatures of PLA. (The lines are just guides for the eye).

DSC curves of the materials prepared at $180{ }^{\circ} \mathrm{C}$ were also recorded after cold crystallization at $85^{\circ} \mathrm{C}$ for $1 \mathrm{~h}$ (Figure 6). Cold crystallization of amorphous PLA pellets is typically performed before their processing, so it does not become sticky or forms clumps during drying [56]. PPAd decreased the final degree of crystallinity of PLA, as calculated by Equation (1), a phenomenon that was also observed in block copolymers PCL and PPAd [57]. Still, all copolymers successfully crystallized in the same temperature as the PLA homopolymer. 


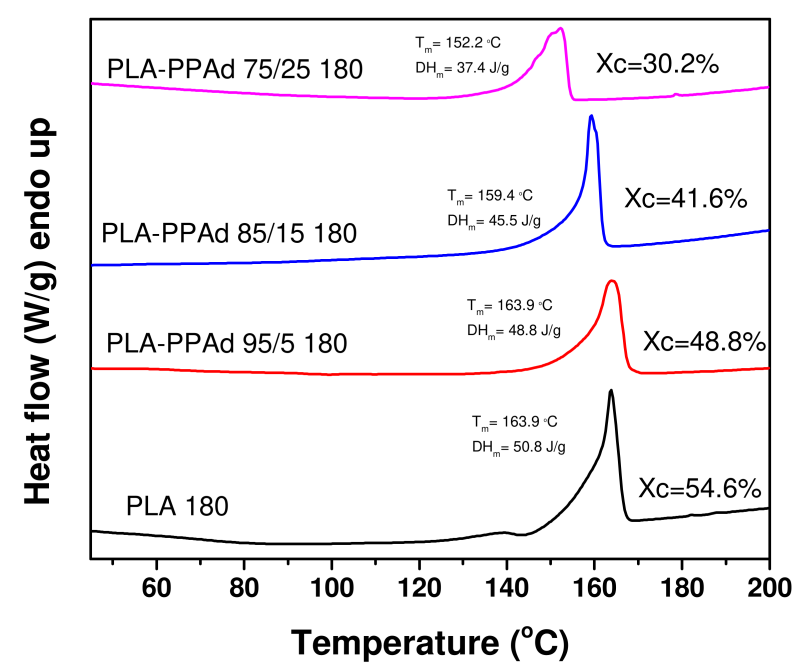

Figure 6. DSC curves of the materials prepared at $180{ }^{\circ} \mathrm{C}$ after cold crystallization at $85^{\circ} \mathrm{C}$ for $1 \mathrm{~h}$.

X-ray diffraction patterns of the materials as-received from the extruder and of PPAd are presented in Figure 7a. PPAd has several crystalline reflections, typical for aliphatic polyesters with an odd number of methylene groups, at 16.8. 18.7, 20.8, 22 and $24^{\circ}$, which agree with previous reports $[33,58,59]$. Its crystal structure hasn't been identified so far. PLA showed two strong reflections at 15.1 and $16.7^{\circ}$, which correspond to the (010) and $(200 / 110)$ crystal planes. Its unit cell is orthorhombic [60]. After annealing (Figure 7b), PLA showed an additional strong reflection at $19^{\circ}$ of the plane (203). The copolymers were received quite amorphous, witnessed by the large halo in the patterns, and after annealing they show the same reflection peaks as PLA. No strong peaks of PPAd can be detected, which implies that crystals of PPAd were not formed, since it crystallized in temperatures lower than room temperature. In a previous study, it was found that PPAd blocks were not able to crystallize in copolymers with PCL [57].
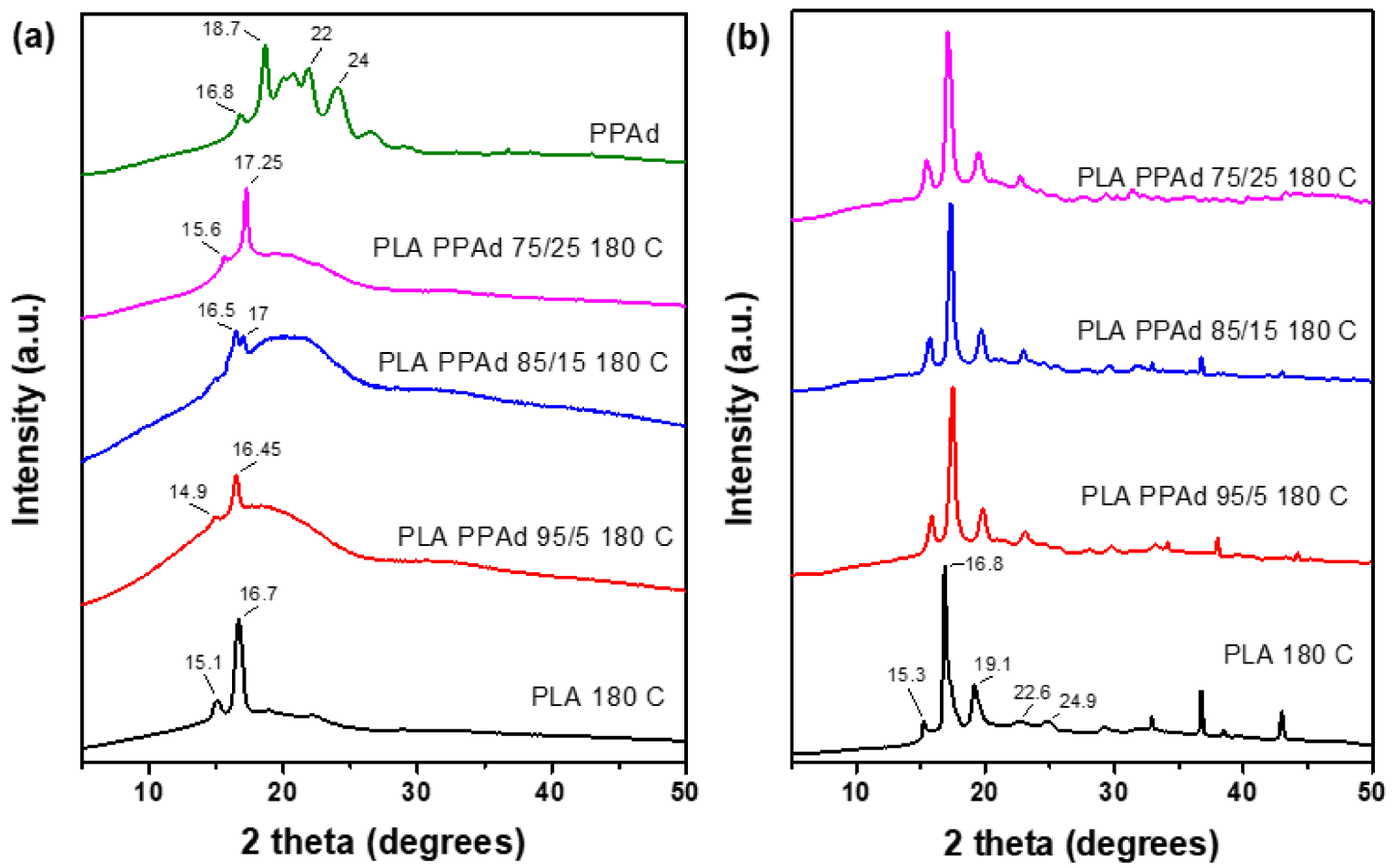

Figure 7. X-Ray diffractograms of PPAd, PLA and their copolymers (a) as received from the extruder and (b) after cold-crystallization at $85^{\circ} \mathrm{C}$ for $1 \mathrm{~h}$. 


\subsection{Tensile Properties}

The PLA homopolymer was very brittle and could not be tested, because the specimens would break during handling. The two samples PLA-PPAd 85/15 and PLA-PPAd $75 / 25$ were the only ones that could be molded into dumbbell shapes specimens for testing; therefore at least $15 \mathrm{wt} \%$ of PPAd oligomer must be added in the synthesis of PLA copolymers to yield adequately plasticized materials. The small amounts of unreacted lactide (see Table 2) can also act as plasticizers for PLA.

The stress-strain curves are shown in Figure 8 and the resulting parameters are shown in Table 4. The elongation at break of PLA with similar molecular weight as PLA 180 prepared for this work ranges from 1-3\% [61]. The typical stress-strain curve of PLA does not have a yield point due to the inherent brittleness of the polymer. With the addition of $15 \mathrm{wt} \%$ PPAd, the stress-strain curves (Figure 8a) exhibited a yield point, and significantly larger elongation at break $(109.1 \pm 45.9 \%)$ in comparison with previously reported tensile properties of PLA [45]. The addition of $25 \mathrm{wt} \%$ PPAd led to soft and weak materials because of the low molecular weight.
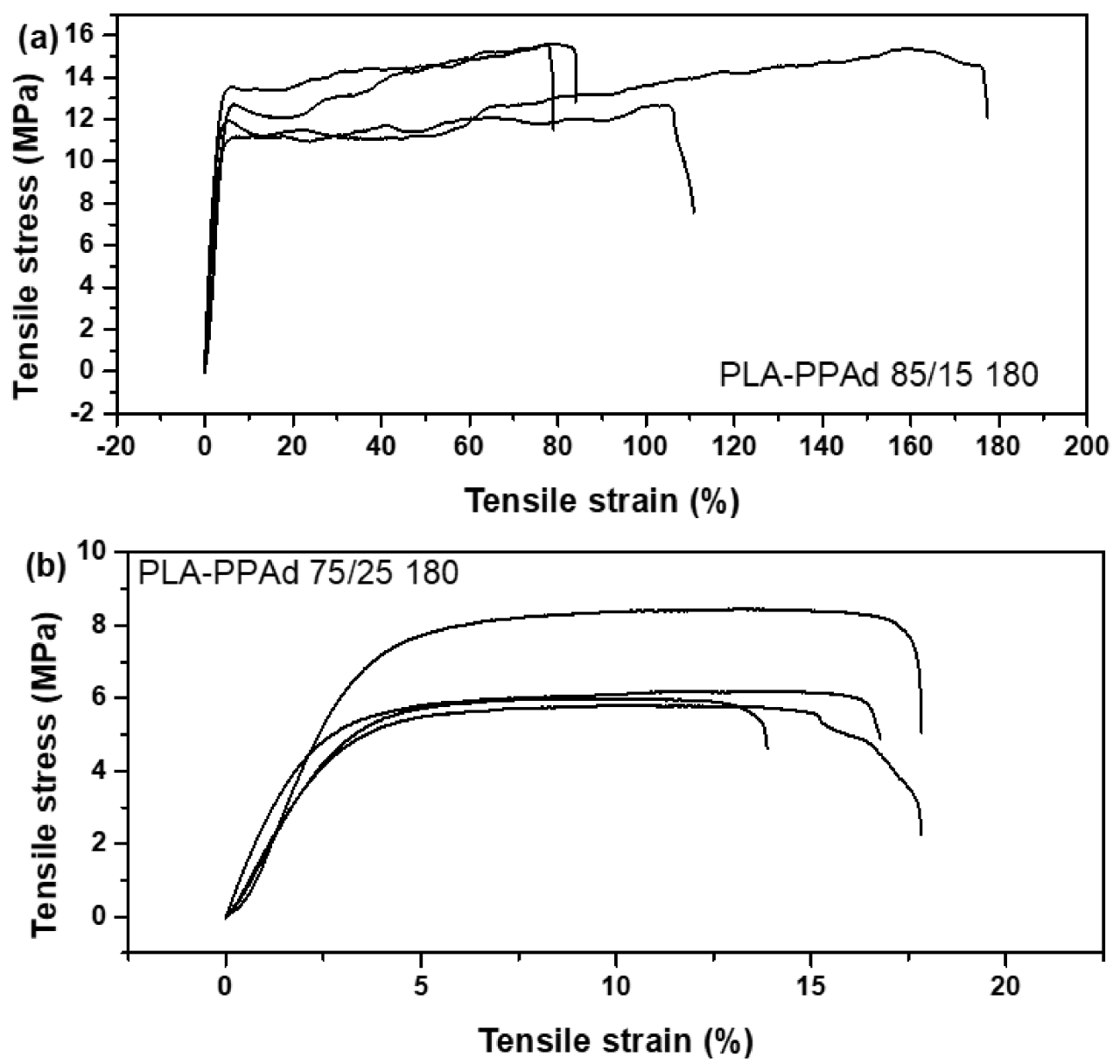

Figure 8. Indicative stress-strain curves of repeated measurements of (a) PLA-PPAd 85/15 and (b) PLA-PPAd 75/25 (amorphous). 
Table 4. Tensile test results. Student's t-test between the two samples yielded $p<0.05$ for tensile stress, elongation and Young's modulus.

\begin{tabular}{cccccc}
\hline \multirow{2}{*}{ Sample } & Tensile Stress at Break & Stress at Yield & Elongation & \multicolumn{2}{c}{ Young's Modulus } \\
\cline { 2 - 5 } & $\mathbf{M P a}$ & $\mathbf{M P a}$ & $\mathbf{\%}$ & $\mathbf{M P a}$ \\
\hline PLA-PPAd 85/15 & $14.8 \pm 1.4$ & $12.3 \pm 1$ & $109.1 \pm 45.9$ & $391.8 \pm 50.1$ \\
\hline PLA-PPAd 75/25 & $7.3 \pm 1.1$ & - & $15.4 \pm 1.8$ & $218.3 \pm 28.1$ \\
\hline
\end{tabular}

\subsection{Water Contact Angle and Enzymatic Hydrolysis}

The factors that affect the biodegradability of polymers are their chemical structure, hydrophilicity, molecular weight, melting point and crystallinity [62,63]. PLA has been considered a biodegradable material as per the definition of IUPAC, which states that biodegradale materials are "polymers susceptible to degradation by biological activity, with the degradation accompanied by a lowering of its molar mass" [64]. Biodegradable plastics are recommended by the European Commission for applications where it is not possible to reduce, reuse or recycle [65]. PLA however is not degradable in an open environment, and requires industrial composting conditions. This very slow rate of degradation is caused by the side methyl group that prevents water and enzymes from easily approaching the labile ester bond.

To explore the effect of hydrophilicity on the hydrolysis rates of polymers, their water contact angle was measured. The effect of PPAd content on the water contact angle of PLA is shown in Figure 9. The water contact angle of polymers depends on their chemical composition and surface properties (roughness, heterogeneity, preparation method), as well as temperature [66]. All contact angle values were $<90^{\circ}$, witnessing the high surface energy and overall wettability of all polymers owning the presence of many polar groups on their molecular structure. PLA had a contact angle of $75 \pm 4.8^{\circ}$, in line with previous reports [67]. To significantly increase the hydrophilicity of PLA, at least $15 \mathrm{wt} \%$ of PPAd must be added. As the PPAd content increased to $25 \mathrm{wt} \%$, the contact angle was further reduced. The increased hydrophilicity can be primarily attributed to the smaller molecular weights of the copolymers, which mean increased concentrations of hydrophilic - $\mathrm{OH}$ and - $\mathrm{COOH}$ groups.

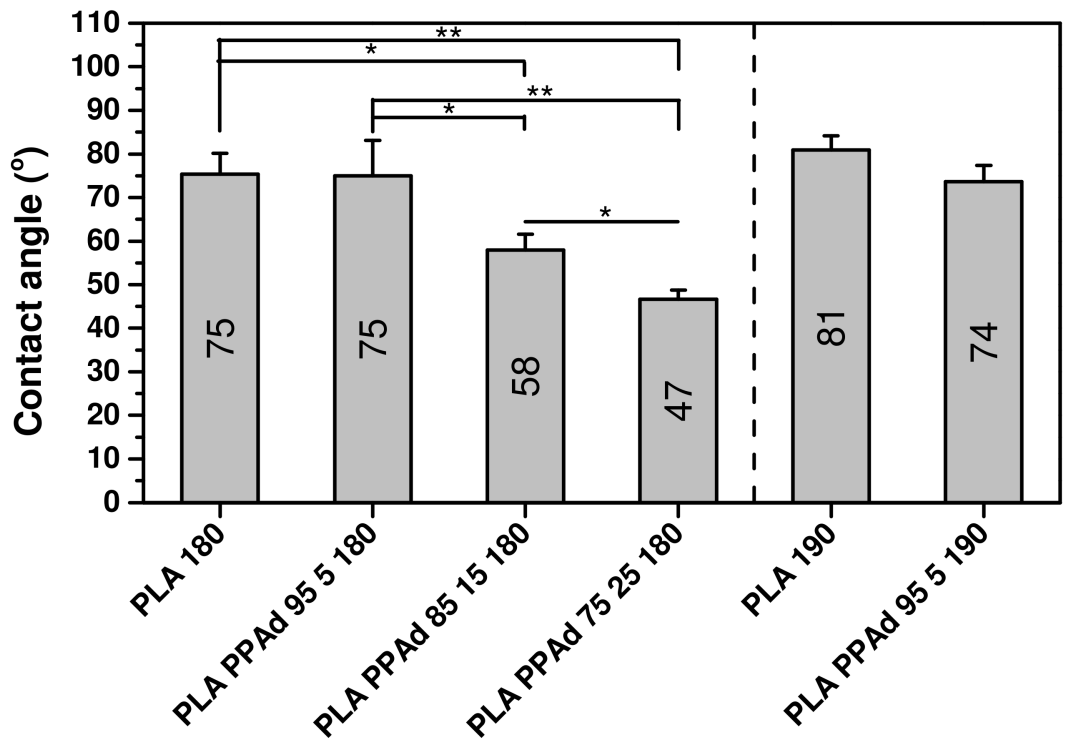

Figure 9. Water contact angle of PLA and the PLA-co-PPAd copolymers. ${ }^{*} p<0.05,{ }^{* *} p<0.01$.

The biodegradation of polymers can be monitored with several different methods, including measuring their weight loss during incubation in the presence of enzymes, 
and microscopic observation of their surfaces. To diminish the effect of crystallinity and dimensions, the specimens used were amorphous films of the same size and similar thickness. In Figure 10, the mass loss of PLA and its copolymers for 30 days of (a) hydrolysis and (b) enzymatic hydrolysis is shown. Cleavage of ester bonds can be catalyzed by enzymes such as lipases, but it can also take place in their absence, since they are susceptible to hydrolytic attack. The PLA homopolymer lost about 3.5\% of its mass after 1 month. The incorporation of PPAd moieties increased the degradation rate, since it is susceptible towards hydrolytic and enzymatic degradation ( $15 \%$ mass loss without enzymes, $100 \%$ mass loss with enzymes). Increasing its content from 5 to $15 \mathrm{wt} \%$ did not significantly affect mass loss; however, further increasing it to $25 \%$ led to a copolymer much more prone to hydrolysis. These results are in line with the contact angle measurements, suggesting that hydrophilicity is the main parameter that controls the biodegradability of the copolyesters.
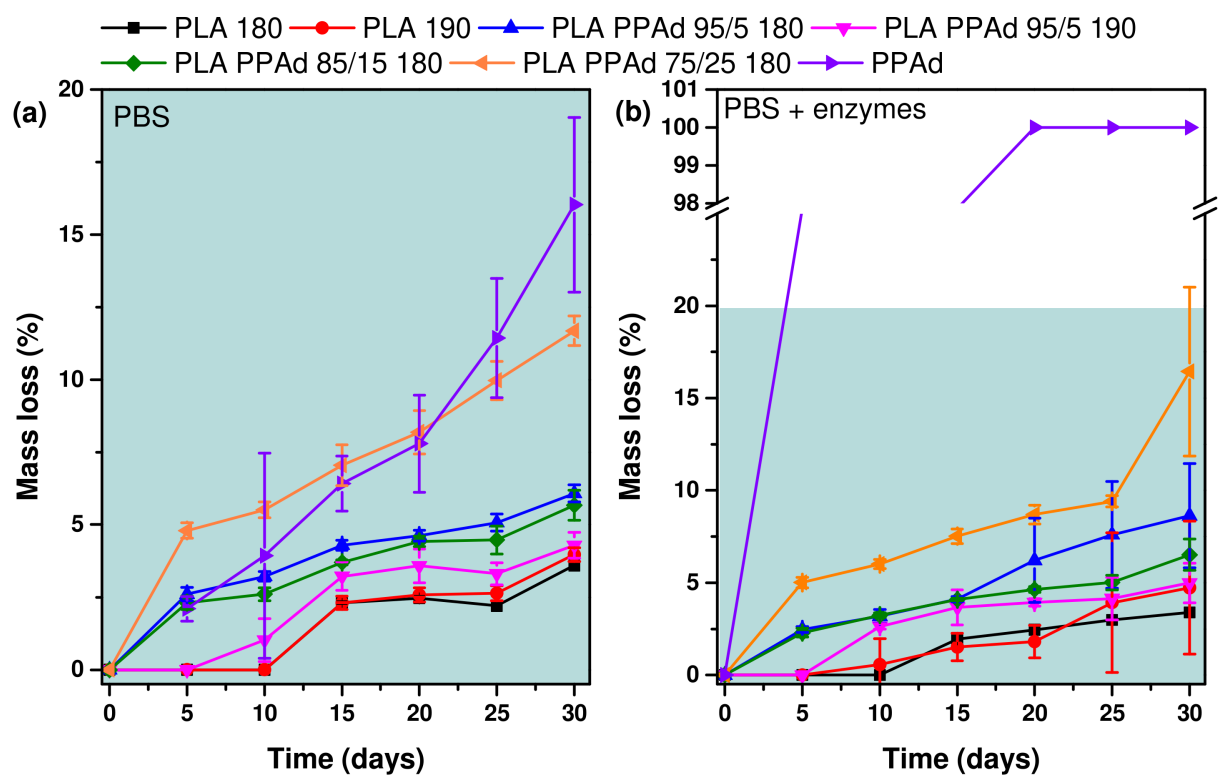

Figure 10. \% Mass loss of the samples during incubation at $37^{\circ} \mathrm{C}$ in (a) PBS and (b) PBS with enzymes ( $0.01 \mathrm{mg} / \mathrm{mL}$ lipase from Pseudomonas cepacia and $0.1 \mathrm{mg} / \mathrm{mL}$ lipase from Rhizopus oryzae). The shaded sections correspond to $20 \%$ mass loss.

The effect of the presence of the enzymes of the final mass loss of the polyesters is presented in Figure 11. The mass loss of PLA did not change significantly in the presence of enzymes, revealing its limited susceptibility to the lipases used. PPAd on the other hand completely degraded after 20 days of incubation with the enzymes, while without them it lost about $7.5 \%$ of its initial mass. Therefore, PPAd can be efficiently degraded by lipases and as a result, the PLA-co-PPAd copolymers lose more weight as they are more prone to be attacked by the enzymes in comparison with neat PLA. Similar results were obtained in previous work on PLA-PPAd blends [51].

The morphology of the sample's surfaces after 30 days of enzymatic hydrolysis was studies with SEM (Figure 12). The surface of the PLA homopolymer did not possess many irregularities, while all the copolymers showed significant deterioration of their surfaces, increased roughness, and holes as well as ridges are visible. These observations are in agreement with the mass loss measurements. 


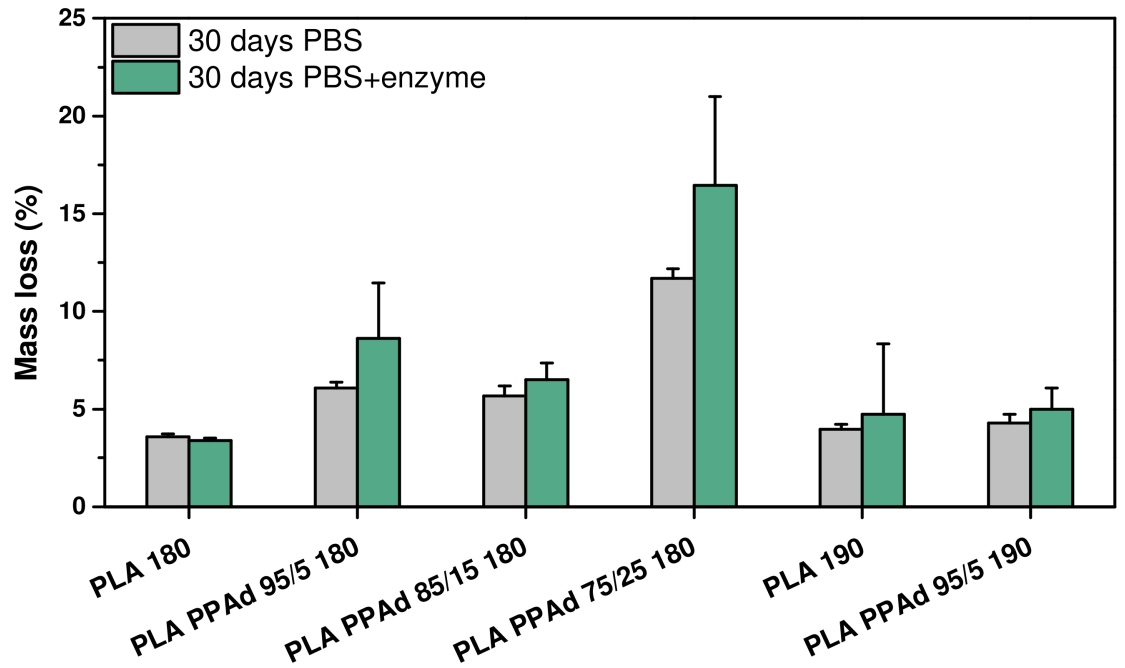

Figure 11. Effect of the presence of enzymes in the hydrolysis of the samples for 30 days.

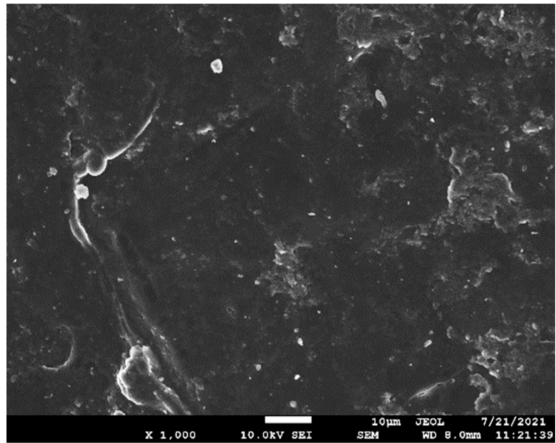

(a) PLA 180

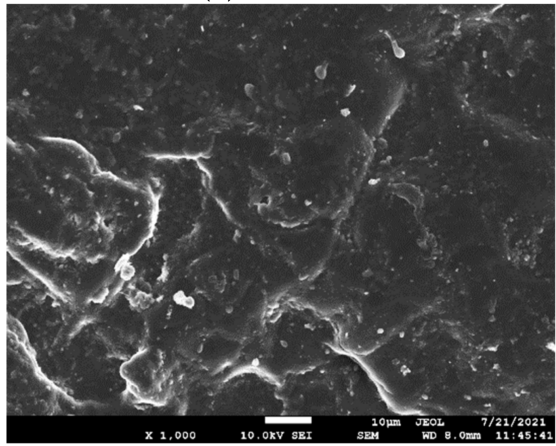

(c) PLA-PPAd 85/15 180

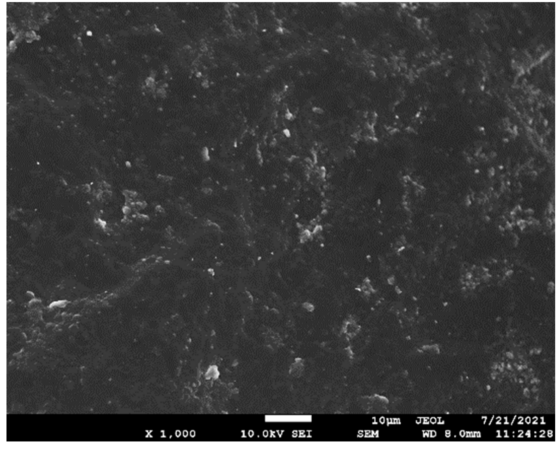

(e) PLA 190

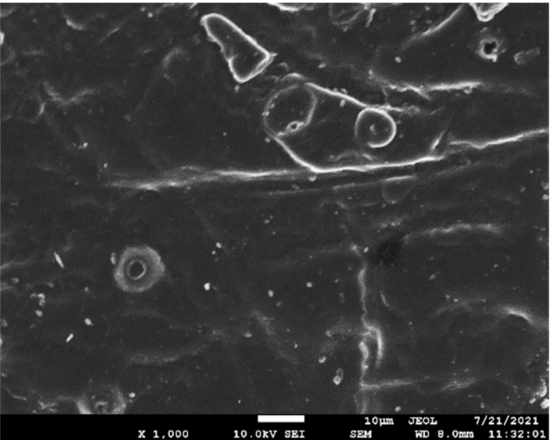

(b) PLA-PPAd 95/5 180

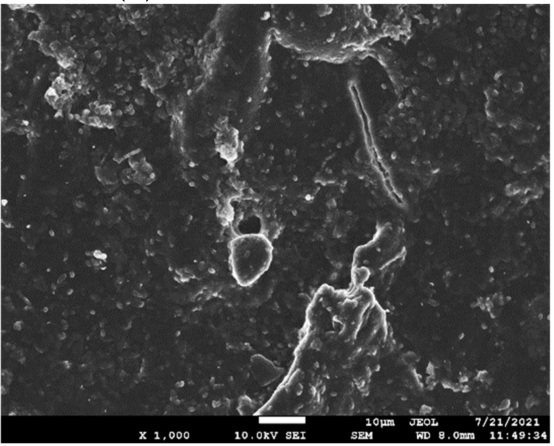

(d) PLA-PPAd 75/25 180

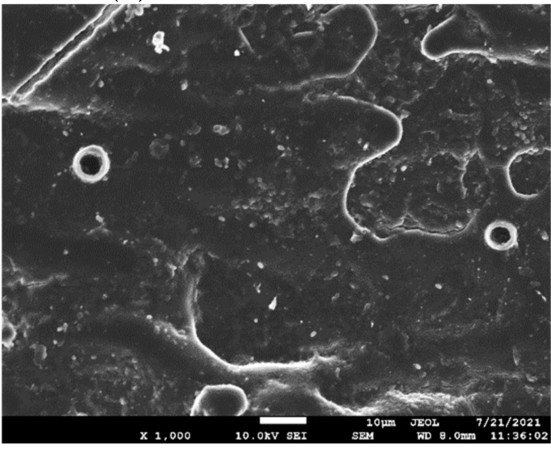

(f) PLA-PPAd 95/5 190

Figure 12. SEM micrographs of the surfaces of the samples after 30 days of enzymatic hydrolysis. 


\section{Conclusions}

PLA-co-PPAd block copolymers were successfully prepared by REX in a torque rheometer, showing potential to be scaled-up by REX in a twin-screw extruder, in an economic and fast way. The optimum reaction temperature was $180^{\circ} \mathrm{C}$, and the reactions were completed in very short times (up to $20 \mathrm{~min}$ ) in comparison with the typical batch-type processes. The molecular weight of the materials was comparable to similar copolymers synthesized with typical ROP and melt polycondensation reactions that require several hours to be completed. The PLA moieties are those that were responsible for crystallization. The addition of $15 \mathrm{wt} \%$ PPAd in the feed successfully increased the elongation of PLA to $\sim 100 \%$, making the addition of a plasticizer unnecessary. PPAd acted as a macroinitiator that reduced the molecular weight of PLA; however, the produced copolymers can find applications as films or base resins in formulations of hot melt adhesives where high viscosity is not required. Finally, PPAd significantly increased the hydrolysis rates of PLA copolymers, which can be controlled by adjusting the PPAd content.

Supplementary Materials: The following are available online at https:/ /www.mdpi.com/article/10.3 390/polym13234121/s1, Figure S1. GPC chromatographs. Figure S2. (a) ATR spectra of PPAd, PLA and their copolymers, (b) zoom in the 1800-1650 cm-1 region of PPAd and the materials prepared at $180{ }^{\circ} \mathrm{C}$. Figure S3. SEM micrographs of cryofractured surfaces in different magnifications $(\times 1500$ and $\times 3500)$.

Author Contributions: Conceptualization, D.N.B.; investigation, D.N.B., Z.T., A.Z., M.A.V. and A.M.; resources, D.N.B.; writing-original draft preparation, Z.T. and A.Z.; writing-review and editing, D.N.B., Z.T. and M.A.V.; visualization, Z.T.; supervision, D.N.B.; project administration, D.N.B. and Z.T.; funding acquisition, D.N.B. All authors have read and agreed to the published version of the manuscript.

Funding: This research received no external funding.

Institutional Review Board Statement: Not applicable.

Informed Consent Statement: Not applicable.

Data Availability Statement: Data is contained within the article or supplementary material.

Acknowledgments: The authors would like to express their gratitude to both Eleni Pavlidou, School of Physics, AUTh, and Chrysanthi Papoulia, student, School of Physics, AUTh for the SEM observations, Maria Kasimatis from Department of Chemistry, University of Athens, for performing the GPC measurements and Michiel Noordam for his help with the statistical analyses.

Conflicts of Interest: The authors declare no conflict of interest.

\section{References}

1. Borrelle, S.B.; Ringma, J.; Lavender Law, K.; Monnahan, C.C.; Lebreton, L.; McGivern, A.; Murphy, E.; Jambeck, J.; Leonard, G.H.; Hilleary, M.A.; et al. Predicted Growth in Plastic Waste Exceeds Efforts to Mitigate Plastic Pollution. Science 2020, 369, 1515-1518. [CrossRef]

2. Kumar, M.; Chen, H.; Sarsaiya, S.; Qin, S.; Liu, H.; Awasthi, M.K.; Kumar, S.; Singh, L.; Zhang, Z.; Bolan, N.S.; et al. Current Research Trends on Micro- and Nano-Plastics as an Emerging Threat to Global Environment: A Review. J. Hazard. Mater. 2021, 409, 124967. [CrossRef]

3. Garcia, J.M.; Robertson, M.L. The Future of Plastics Recycling. Science 2017, 358, 870-872. [CrossRef] [PubMed]

4. Roy, P.; Mohanty, A.K.; Wagner, A.; Sharif, S.; Khalil, H.; Misra, M. Impacts of COVID-19 Outbreak on the Municipal Solid Waste Management: Now and beyond the Pandemic. ACS Environ. Au 2021, 1, 32-45. [CrossRef]

5. European Comission Plastics. Available online: https://ec.europa.eu/environment/topics/plastics (accessed on 3 September 2021).

6. Pellis, A.; Malinconico, M.; Guarneri, A.; Gardossi, L. Renewable Polymers and Plastics: Performance beyond the Green. New Biotechnol. 2021, 60, 146-158. [CrossRef]

7. Zhang, Q.; Song, M.; Xu, Y.; Wang, W.; Wang, Z.; Zhang, L. Bio-Based Polyesters: Recent Progress and Future Prospects. Prog. Polym. Sci. 2021, 120, 101430. [CrossRef]

8. Amulya, K.; Katakojwala, R.; Ramakrishna, S.; Venkata Mohan, S. Low Carbon Biodegradable Polymer Matrices for Sustainable Future. Compos. Part C Open Access 2021, 4, 100111. [CrossRef] 
9. Chinthapalli, R.; Skoczinski, P.; Carus, M.; Baltus, W.; De Guzman, D.; Käb, H.; Raschka, A.; Ravenstijn, J. Biobased Building Blocks and Polymers-Global Capacities, Production and Trends, 2018-2023. Ind. Biotechnol. 2019, 15, 237-241. [CrossRef]

10. Barron, A.; Sparks, T.D. Commercial Marine-Degradable Polymers for Flexible Packaging. iScience 2020, 23, 101353. [CrossRef] [PubMed]

11. Bioplastics, E. Bioplastics Market Data. Available online: https://www.european-bioplastics.org/market/ (accessed on 3 September 2021).

12. Raquez, J.M.; Ramy-Ratiarison, R.; Murariu, M.; Dubois, P. Reactive Extrusion of PLA-Based Materials: From Synthesis to Reactive Melt-Blending. RSC Polym. Chem. Ser. 2015, 12, 101.

13. Jem, K.J.; Tan, B. The Development and Challenges of Poly (Lactic Acid) and Poly (Glycolic Acid). Adv. Ind. Eng. Polym. Res. 2020, 3, 60-70. [CrossRef]

14. Farrington, D.W.; Lunt, J.; Davies, S.; Blackburn, R.S. Poly(lactic acid) fibers (PLA). In Polyesters and Polyamides; Deopura, B.L., Alagirusamy, R., Joshi, M., Gupta, B.B.T.-P.P., Eds.; Woodhead Publishing: Sawston, UK, 2008; pp. 140-170. ISBN 9781845692988.

15. Balla, E.; Daniilidis, V.; Karlioti, G.; Kalamas, T.; Stefanidou, M.; Bikiaris, N.D.; Vlachopoulos, A.; Koumentakou, I.; Bikiaris, D.N. Poly(Lactic Acid): A Versatile Biobased Polymer for the Future with Multifunctional Properties-from Monomer Synthesis, Polymerization Techniques and Molecular Weight Increase to PLA Applications. Polymers 2021, 13, 1822. [CrossRef]

16. Raquez, J.M.; Habibi, Y.; Murariu, M.; Dubois, P. Polylactide (PLA)-Based Nanocomposites. Prog. Polym. Sci. 2013, 38, 1504-1542. [CrossRef]

17. Masutani, K.; Kimura, Y. PLA Synthesis. from the Monomer to the Polymer. In Poly(lactic acid) Science and Technology: Processing, Properties, Additives and Applications; Masutani, K., Kimura, Y., Eds.; The Royal Society of Chemistry: London, UK, 2014; pp. 1-26. ISBN 978-1-78262-480-6. [CrossRef]

18. Ramot, Y.; Haim-Zada, M.; Domb, A.J.; Nyska, A. Biocompatibility and Safety of PLA and Its Copolymers. Adv. Drug Deliv. Rev. 2016, 107, 153-162. [CrossRef]

19. Martin, O.; Avérous, L. Poly(Lactic Acid): Plasticization and Properties of Biodegradable Multiphase Systems. Polymer 2001, 42, 6209-6219. [CrossRef]

20. Murariu, M.; Dubois, P. PLA Composites: From Production to Properties. Adv. Drug Deliv. Rev. 2016, 107, 17-46. [CrossRef] [PubMed]

21. Xiao, R.Z.; Zeng, Z.W.; Zhou, G.L.; Wang, J.J.; Li, F.Z.; Wang, A.M. Recent Advances in PEG-PLA Block Copolymer Nanoparticles. Int. J. Nanomed. 2010, 5, 1057-1065. [CrossRef]

22. Zhang, K.; Tang, X.; Zhang, J.; Lu, W.; Lin, X.; Zhang, Y.; Tian, B.; Yang, H.; He, H. PEG-PLGA Copolymers: Their Structure and Structure-Influenced Drug Delivery Applications. J. Control. Release 2014, 183, 77-86. [CrossRef]

23. Stevels, W.M.; Bernard, A.; Van De Witte, P.; Dijkstra, P.J.; Feijen, J. Block Copolymers of Poly(L-Lactide) and Poly( $\varepsilon$-Caprolactone) or Poly(Ethylene Glycol) Prepared by Reactive Extrusion. J. Appl. Polym. Sci. 1996, 62, 1295-1301. [CrossRef]

24. Jacobs, C.; Dubois, P.; Jerome, R.; Teyssie, P. Macromolecular Engineering of Polylactones and Polylactides. 5. Synthesis and Characterization of Diblock Copolymers Based on Poly-e-Caprolactone and Poly(L,L or D,L)Lactide by Aluminum Alkoxides. Macromolecules 1991, 24, 3027-3034. [CrossRef]

25. Supthanyakul, R.; Kaabbuathong, N.; Chirachanchai, S. Poly(L-Lactide-b-Butylene Succinate-b-L-Lactide) Triblock Copolymer: A Multi-Functional Additive for PLA/PBS Blend with a Key Performance on Film Clarity. Polym. Degrad. Stab. 2017, 142, 160-168. [CrossRef]

26. Chrysafi, I.; Pavlidou, E.; Christodoulou, E.; Vourlias, G.; Klonos, P.A.; Kyritsis, A.; Bikiaris, D.N. Effects of Poly(Hexylene Succinate) Amount on the Crystallization and Molecular Mobility of Poly(Lactic Acid) Copolymers. Thermochim. Acta 2021, 698, 178883. [CrossRef]

27. Müller, A.J.; Avila, M.; Saenz, G.; Salazar, J. Crystallization of PLA-Based Materials. In Poly(lactic acid) Science and Technology: Processing, Properties, Additives and Applications; Masutani, K., Kimura, Y., Eds.; The Royal Society of Chemistry: London, UK, 2014; pp. 66-98. ISBN 978-1-78262-480-6. [CrossRef]

28. Polen, T.; Spelberg, M.; Bott, M. Toward Biotechnological Production of Adipic Acid and Precursors from Biorenewables. J. Biotechnol. 2013, 167, 75-84. [CrossRef]

29. Unlu, S.; Niu, W.; ar Demirel, Y. Bio-Based Adipic Acid Production: Feasibility Analysis Using a Multi-Criteria Decision Matrix. Biofuels Bioprod. Biorefining 2020, 14, 794-807. [CrossRef]

30. Skoog, E.; Shin, J.H.; Saez-Jimenez, V.; Mapelli, V.; Olsson, L. Biobased Adipic Acid-The Challenge of Developing the Production Host. Biotechnol. Adv. 2018, 36, 2248-2263. [CrossRef]

31. Jian, J.; Xiangbin, Z.; Xianbo, H. An Overview on Synthesis, Properties and Applications of Poly(Butylene-Adipate-coTerephthalate)-PBAT. Adv. Ind. Eng. Polym. Res. 2020, 3, 19-26. [CrossRef]

32. Zorba, T.; Chrissafis, K.; Paraskevopoulos, K.M.; Bikiaris, D.N. Synthesis, Characterization and Thermal Degradation Mechanism of Three Poly(Alkylene Adipate)s: Comparative Study. Polym. Degrad. Stab. 2007, 92, 222-230. [CrossRef]

33. Soccio, M.; Lotti, N.; Finelli, L.; Gazzano, M.; Munari, A. Aliphatic Poly(Propylene Dicarboxylate)s: Effect of Chain Length on Thermal Properties and Crystallization Kinetics. Polymer 2007, 48, 3125-3136. [CrossRef]

34. Kumar, S.; Rohindra, D.; Lata, R.; Kuboyama, K.; Ougizawa, T. Structural Changes in Poly(Trimethylene Adipate) and Poly(Trimethylene Succinate) During Melt Crystallization Studied Using In Situ Infrared Spectroscopy. Appl. Spectrosc. 2017, 71, 2488-2496. [CrossRef] 
35. Jacobsen, S.; Fritz, H.G.; Degée, P.; Dubois, P.; Jérôme, R. Continuous Reactive Extrusion Polymerisation of L-Lactide-An Engineering View. In Proceedings of the Macromolecular Symposia; WILEY-VCH Verlag GmbH \& Co. KGaA: Weinheim, Germany, 2000; Volume 153, pp. 261-273.

36. Jacobsen, S.; Fritz, H.G.; Degée, P.; Dubois, P.; Jérôme, R. Single-Step Reactive Extrusion of PLLA in a Corotating Twin-Screw Extruder Promoted by 2-Ethylhexanoic Acid Tin(II) Salt and Triphenylphosphine. Polymer 2000, 41, 3395-3403. [CrossRef]

37. Degée, P.; Dubois, P.; Jérôme, R.; Jacobsen, S.; Fritz, H.G. New Catalysis for Fast Bulk Ring-Opening Polymerization of Lactide Monomers. In Macromolecular Symposia; WILEY-VCH Verlag GmbH \& Co. KGaA: Weinheim, Germany, 1999; Volume 144, pp. 289-302. [CrossRef]

38. Degé, P.H.; Dubois, P.H.; Jacobsen, S.; Fritz, H.G.; Jérome, R. Beneficial Effect of Triphenylphosphine on the Bulk Polymerization of L, L-Lactide Promoted by 2-Ethyihexanoic Acid Tin (II) Salt. J. Polym. Sci. Part A Polym. Chem. 1999, 37, 2413-2420. [CrossRef]

39. Ramy-Ratiarison, R.; Lison, V.; Raquez, J.-M.; Duquesne, E.; Dubois, P. Synthesis of Melt-Processable PLA-Based Stereocomplexes through a Sustainable Melt-Approach. Green Chem. 2014, 16, 1759-1763. [CrossRef]

40. Gallos, A.; Fontaine, G.; Bourbigot, S. Reactive Extrusion of Stereocomplexed Poly-L,D-Lactides: Processing, Characterization, and Properties. Macromol. Mater. Eng. 2013, 298, 1016-1023. [CrossRef]

41. Jacobsen, S.; Degée, P.; Fritz, H.G.; Dubois, P.; Jérôme, R. Polylactide (PLA)—A New Way of Production. Polym. Eng. Sci. 1999, 39, 1311-1319. [CrossRef]

42. Karavelidis, V.; Bikiaris, D.; Avgoustakis, K. New Thermosensitive Nanoparticles Prepared by Biocompatible Pegylated Aliphatic Polyester Block Copolymers for Local Cancer Treatment. J. Pharm. Pharmacol. 2015, 67, 215-230. [CrossRef]

43. Karavelidis, V.; Giliopoulos, D.; Karavas, E.; Bikiaris, D. Nanoencapsulation of a Water Soluble Drug in Biocompatible Polyesters. Effect of Polyesters Melting Point and Glass Transition Temperature on Drug Release Behavior. Eur. J. Pharm. Sci. 2010, 41, 636-643. [CrossRef] [PubMed]

44. Bikiaris, D.N.; Papageorgiou, G.Z.; Achilias, D.S. Synthesis and comparative biodegradability studies of three poly (alkylene succinate)s. Polym. Deg. And Stab. 2006, 91,31-43. [CrossRef]

45. Grigora, M.E.; Terzopoulou, Z.; Tsongas, K.; Klonos, P.; Kalafatakis, N.; Bikiaris, D.N.; Kyritsis, A.; Tzetzis, D. Influence of Reactive Chain Extension on the Properties of 3d Printed Poly(Lactic Acid) Constructs. Polymers 2021, 13, 1381. [CrossRef]

46. Mysiukiewicz, O.; Barczewski, M.; Skórczewska, K.; Matykiewicz, D. Correlation between Processing Parameters and Degradation of Different Polylactide Grades during Twin-Screw Extrusion. Polymers 2020, 12, 1333. [CrossRef]

47. Nanaki, S.; Viziridou, A.; Zamboulis, A.; Kostoglou, M.; Papageorgiou, G.Z.; Bikiaris, D.N. New Biodegradable Poly(l-Lactide)Block-Poly(Propylene Adipate) Copolymer Microparticles for Long-Acting Injectables of Naltrexone Drug. Polymers 2020, $12,852$. [CrossRef]

48. Hu, Y.; Daoud, W.A.; Cheuk, K.K.L.; Lin, C.S.K. Newly Developed Techniques on Polycondensation, Ring-Opening Polymerization and Polymer Modification: Focus on Poly(Lactic Acid). Materials 2016, 9, 133. [CrossRef]

49. Sin, L.T.; Tueen, B.S. Synthesis and Production of Poly(Lactic Acid). In Polylactic Acid; Sin, L.T., Tueen, B.S.B.T.-P.A., Second, E., Eds.; William Andrew Publishing: Norwich, NY, USA, 2019; pp. 53-95. ISBN 978-0-12-814472-5.

50. Henton, D.E.; Gruber, P.; Lunt, J.; Randall, J. Polylactic acid technology. In Natural Fibers, Biopolymers, and Biocomposites; CRC Press: Boca Raton, FL, USA, 2005; Volume 16, pp. 527-577. ISBN 9780203508206.

51. Nanaki, S.; Barmpalexis, P.; Iatrou, A.; Christodoulou, E.; Kostoglou, M.; Bikiaris, D.N. Risperidone Controlled Release Microspheres Based on Poly(Lactic Acid)-Poly(Propylene Adipate) Novel Polymer Blends Appropriate for Long Acting Injectable Formulations. Pharmaceutics 2018, 10, 130. [CrossRef]

52. Soccio, M.; Lotti, N.; Finelli, L.; Gazzano, M.; Munari, A. Miscibility of Biodegradable Poly(Propylene Succinate)/Poly(Propylene Adipate) Blends: Effect of the Transesterification Reactions. Eur. Polym. J. 2009, 45, 3236-3248. [CrossRef]

53. Bikiaris, D.; Nanaki. Pantopoulos Synthesis of Biocompatible Poly( $\varepsilon$-Caprolactone)-Block-Poly(Propylene Adipate) Copolymers Appropriate for Drug Nanoencapsulation in the Form of Core-Shell Nanoparticles. Int. J. Nanomed. 2011, 6, 2981. [CrossRef]

54. di Lorenzo, M.L. The Crystallization and Melting Processes of Poly (L-lactic Acid). Macromol. Symp. 2006, 234, 176-183. [CrossRef]

55. di Lorenzo, M.L. Crystallization Behavior of Poly (L-Lactic Acid). Eur. Polym. J. 2005, 41, 569-575. [CrossRef]

56. Tarani, E.; Črešnar, K.P.; Zemljič, L.F.; Chrissafis, K.; Papageorgiou, G.Z.; Lambropoulou, D.; Zamboulis, A.; Bikiaris, D.N.; Terzopoulou, Z. Cold Crystallization Kinetics and Thermal Degradation of PLA Composites with Metal Oxide Nanofillers. Appl. Sci. 2021, 11, 3004. [CrossRef]

57. Nanaki, S.G.; Papageorgiou, G.Z.; Bikiaris, D.N. Crystallization of Novel Poly ( $\in$-Caprolactone)-Block-Poly (Propylene Adipate) Copolymers. J. Therm. Anal. Calorim. 2012, 108, 633-645. [CrossRef]

58. Bikiaris, D.N.; Papageorgiou, G.Z.; Giliopoulos, D.J.; Stergiou, C.A. Correlation between Chemical and Solid-State Structures and Enzymatic Hydrolysis in Novel Biodegradable Polyesters. The Case of Poly (Propylene Alkanedicarboxylate) s. Macromol. Biosci. 2008, 8, 728-740. [CrossRef]

59. Papageorgiou, G.Z.; Bikiaris, D.N. Crystallization and Melting Behavior of Three Biodegradable Poly(Alkylene Succinates). A Comparative Study. Polymer 2005, 46, 12081-12092. [CrossRef]

60. Zhang, J.; Tashiro, K.; Tsuji, H.; Domb, A.J. Disorder-to-Order Phase Transition and Multiple Melting Behavior of Poly (L-Lactide) Investigated by Simultaneous Measurements of WAXD and DSC. Macromolecules 2008, 41, 1352-1357. [CrossRef]

61. Burzic, I.; Pretschuh, C.; Kaineder, D.; Eder, G.; Smilek, J.; Másilko, J.; Kateryna, W. Impact Modification of PLA Using Biobased Biodegradable PHA Biopolymers. Eur. Polym. J. 2019, 114, 32-38. [CrossRef] 
62. Tokiwa, Y.; Calabia, B.P. Biodegradability and Biodegradation of Poly (Lactide). Appl. Microbiol. Biotechnol. 2006, 72, $244-251$. [CrossRef]

63. Gigli, M.; Quartinello, F.; Soccio, M.; Pellis, A.; Lotti, N.; Guebitz, G.M.; Licoccia, S.; Munari, A. Enzymatic Hydrolysis of Poly(1,4Butylene 2,5-Thiophenedicarboxylate) (PBTF) and Poly(1,4-Butylene 2,5-Furandicarboxylate) (PBF) Films: A Comparison of Mechanisms. Environ. Int. 2019, 130, 104852. [CrossRef]

64. Horie, K.; Barón, M.; Fox, R.B.; He, J.; Hess, M.; Kahovec, J.; Kitayama, T.; Kubisa, P.; Maréchal, E.; Mormann, W. Definitions of Terms Relating to Reactions of Polymers and to Functional Polymeric Materials (IUPAC Recommendations 2003). Pure Appl. Chem. 2004, 76, 889-906. [CrossRef]

65. European Commision. Bio-Based, Biodegradable and Compostable Plastics. Available online: https://ec.europa.eu/ environment/topics/plastics/bio-based-biodegradable-and-compostable-plastics (accessed on 10 September 2021).

66. Yekta-Fard, M.; Ponter, A.B. Factors Affecting the Wettability of Polymer Surfaces. J. Adhes. Sci. Technol. 1992, 6, 253-277. [CrossRef]

67. Bitinis, N.; Verdejo, R.; Maya, E.M.; Espuche, E.; Cassagnau, P.; Lopez-Manchado, M.A. Physicochemical Properties of Organoclay Filled Polylactic Acid/Natural Rubber Blend Bionanocomposites. Compos. Sci. Technol. 2012, 72, 305-313. [CrossRef] 